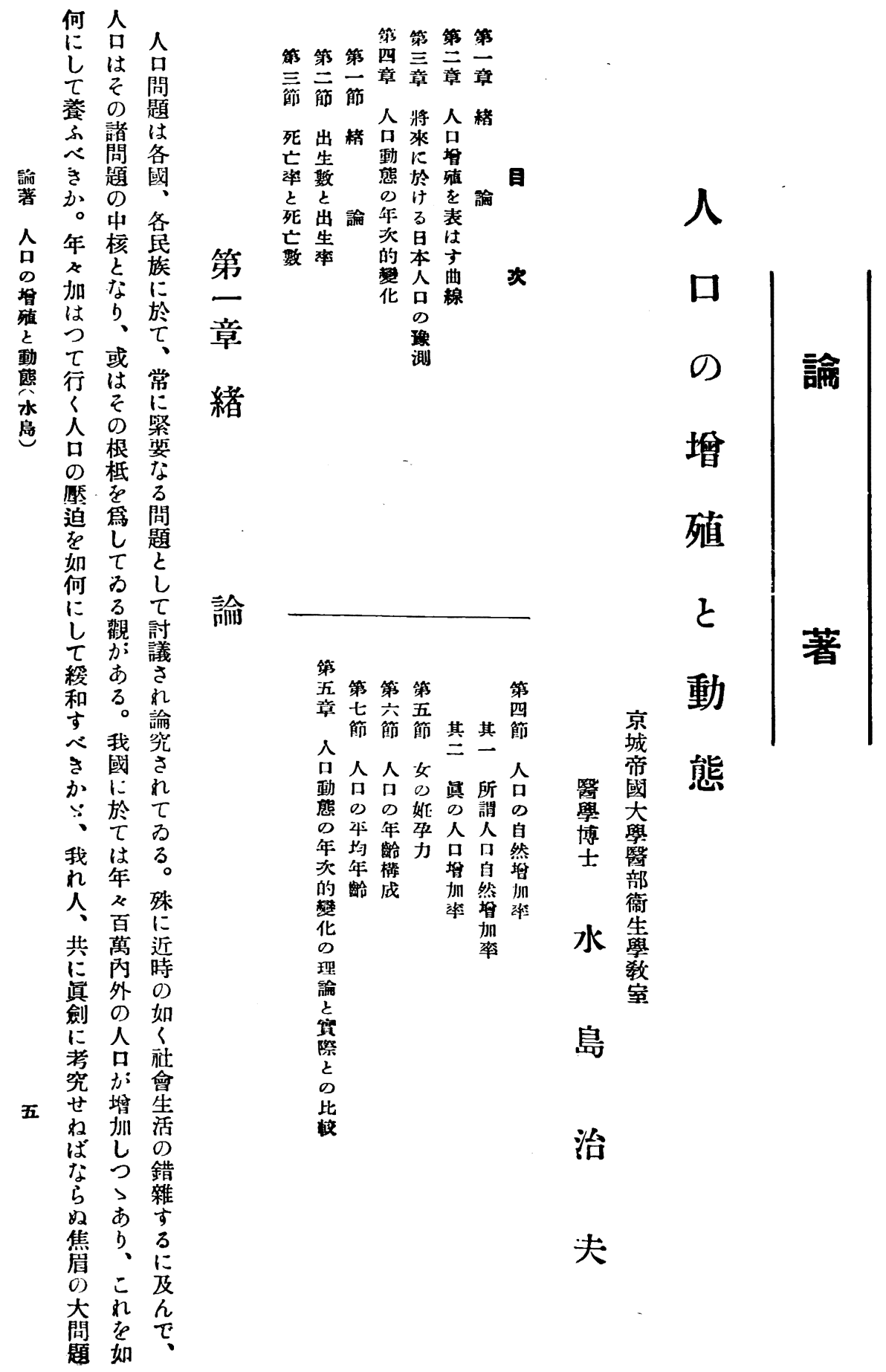


吕公艺線

式年乃造土

最合合全

。唱はの只

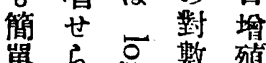

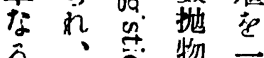

形久線市

は ᄂ 量式數

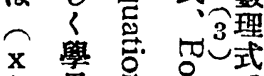

者界过资

以点践蛋峾

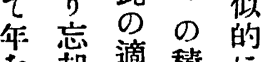

表郬適檞表

は焉知政

し元知常查

y落線结

人员基

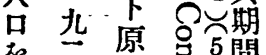

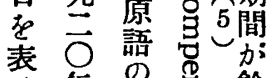

年年学餘

守

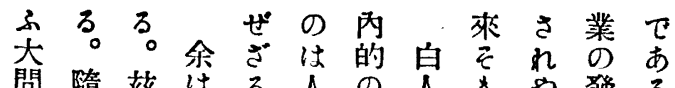

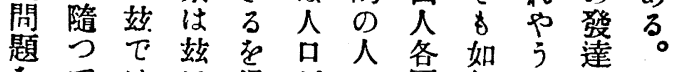
名てはに得が口國何か:に過 或之人人、去旺缺にに心依剩 一の口只いん迫 あし二b众 角內の問。にに宁餘口論

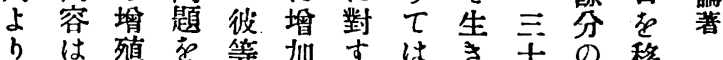
鮡抽之社のしる近ん年人兵人

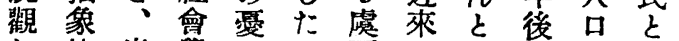

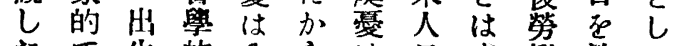

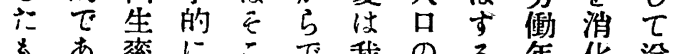
の り 率にこだ我の る 八

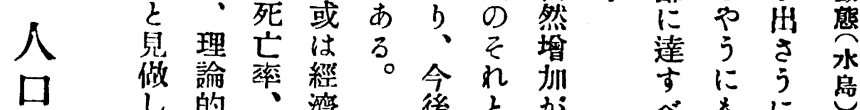

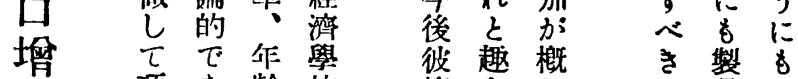
殖項市龄的 等 它 し 人品世

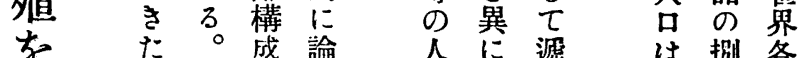
表 心人等議 口年減 既け地 は t 曲 線 口の 問諸飞 加る。

今 $の$ 門 動對停し あ 迄抗は 實態策 此彼る。落 際 の学等。而生逐了 に年考、白而游 取次笔而人知增さ

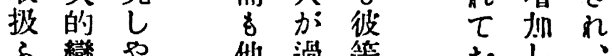
向變や 5 他過等

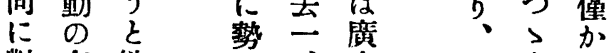
對有欲よ大大此あに し様す主な

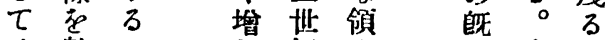
は數の 扠紀士 土存产狹 意理で卞の胥 人兒い に統は間占は口居 滿計な 民に有。の制口 た的心。族圣し 䃉限さ

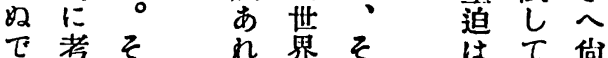
あ察は $は$ ばに

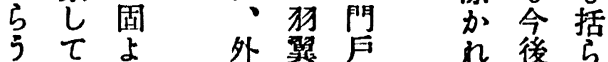
が見b 部苞を な抶れ

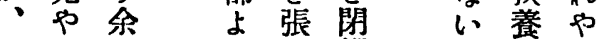
こう の b b 顉 れ 能計 し 賁と 与欲力霸元本据し 亦す外口艺る 民はて 人る枤唱了方多る

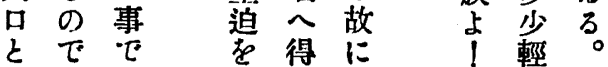

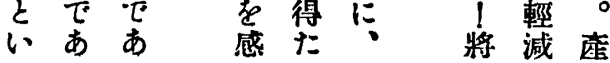



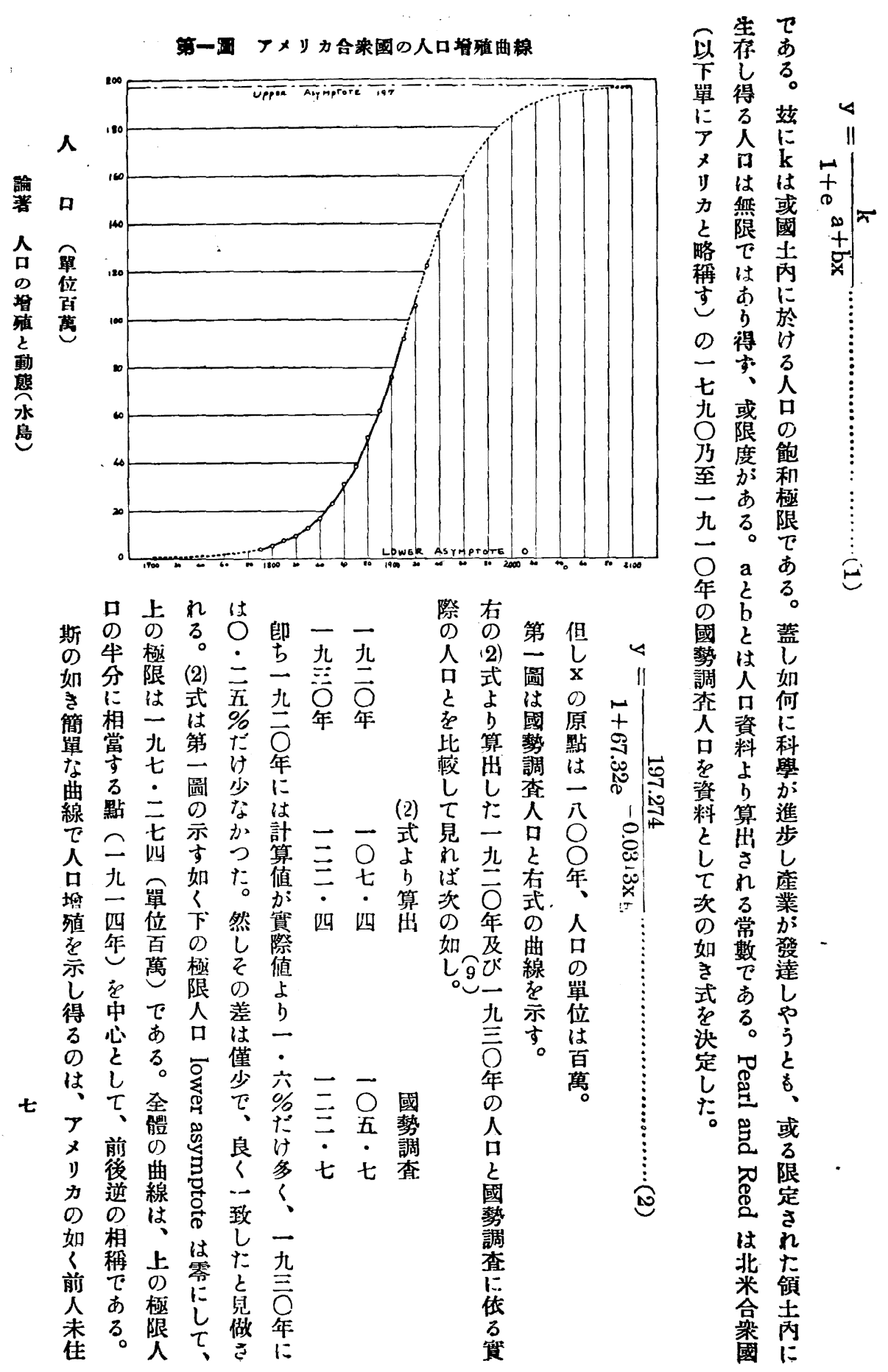


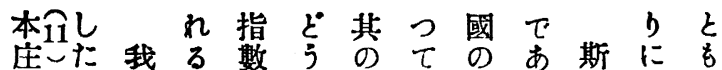

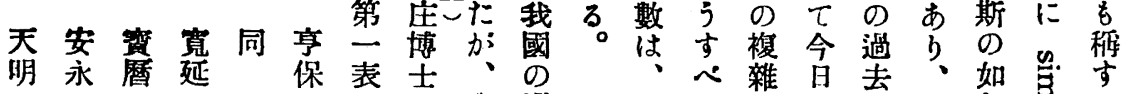

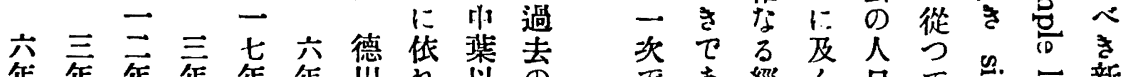

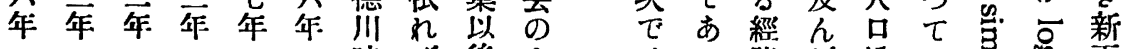
時は後人极路だ增吕骂天

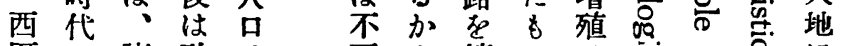

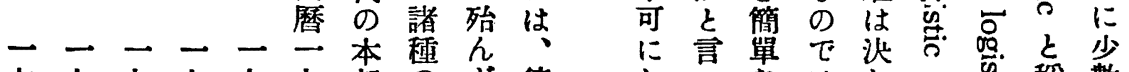

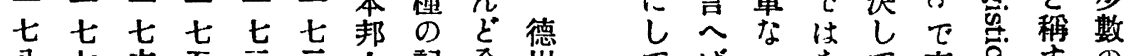

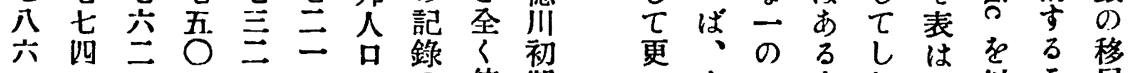

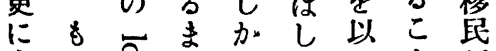
示止以高し品

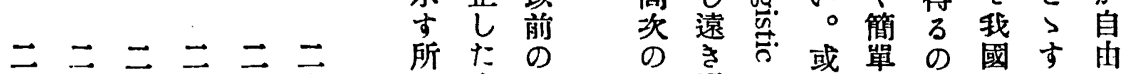

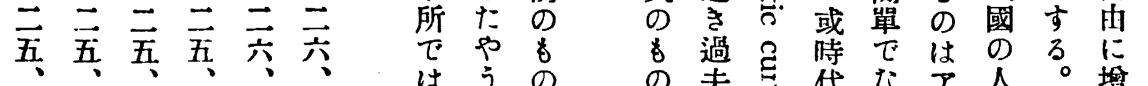
○北九住は

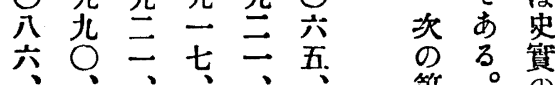
四四四八刀四第而示

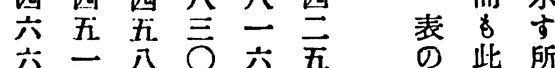
の如 の 所 虫葉

寛安明寶延亭 以 政 永 和 曆 豙 保 岇杂吾六元年

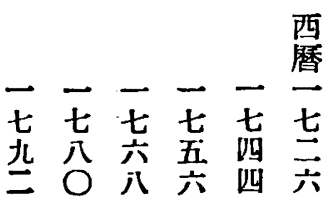

豆亲亲亲亲 後 $\tau$

の 到

人 底

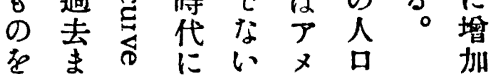

八 0 二 0 - 五

品確

餘な

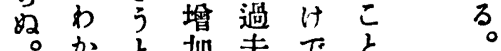

何つ試し市あは。斯

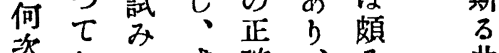

九五六五西

筫

賽は

に知

近

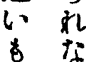

の

$\because 0=\rightarrow \equiv$

信 德

娄方或 碓

用り、の時な人無線 用: は代方然

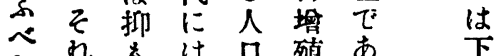

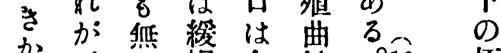

は百理慢今線。10 極

○以相な知し暏 限

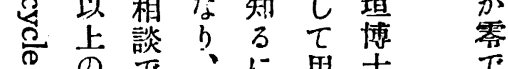

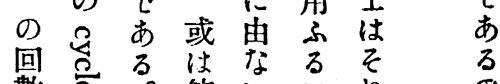

曲示了し、占試特

し川線し場或決古み 徴

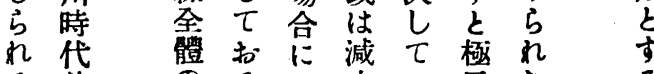

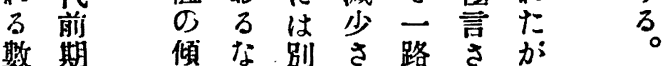

西 $\bigcirc$ 八四九

四 ○五吾五

稘

かi に

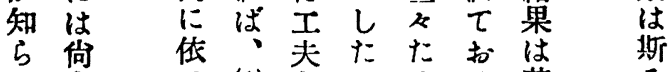

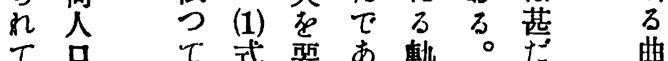

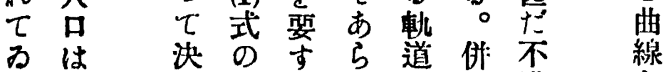

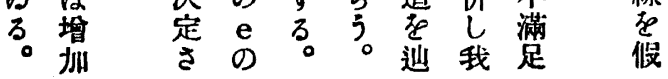




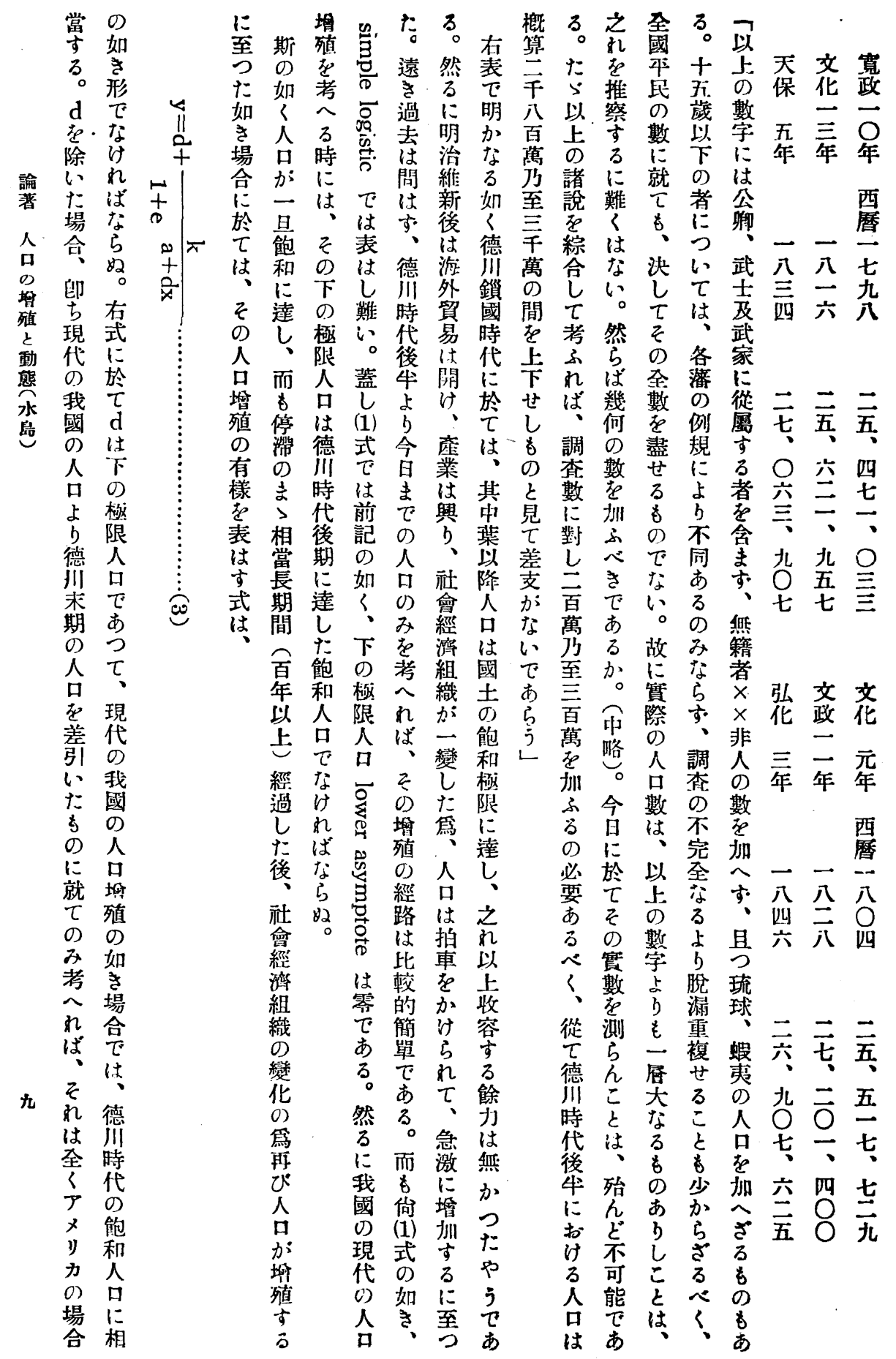


I卷 428

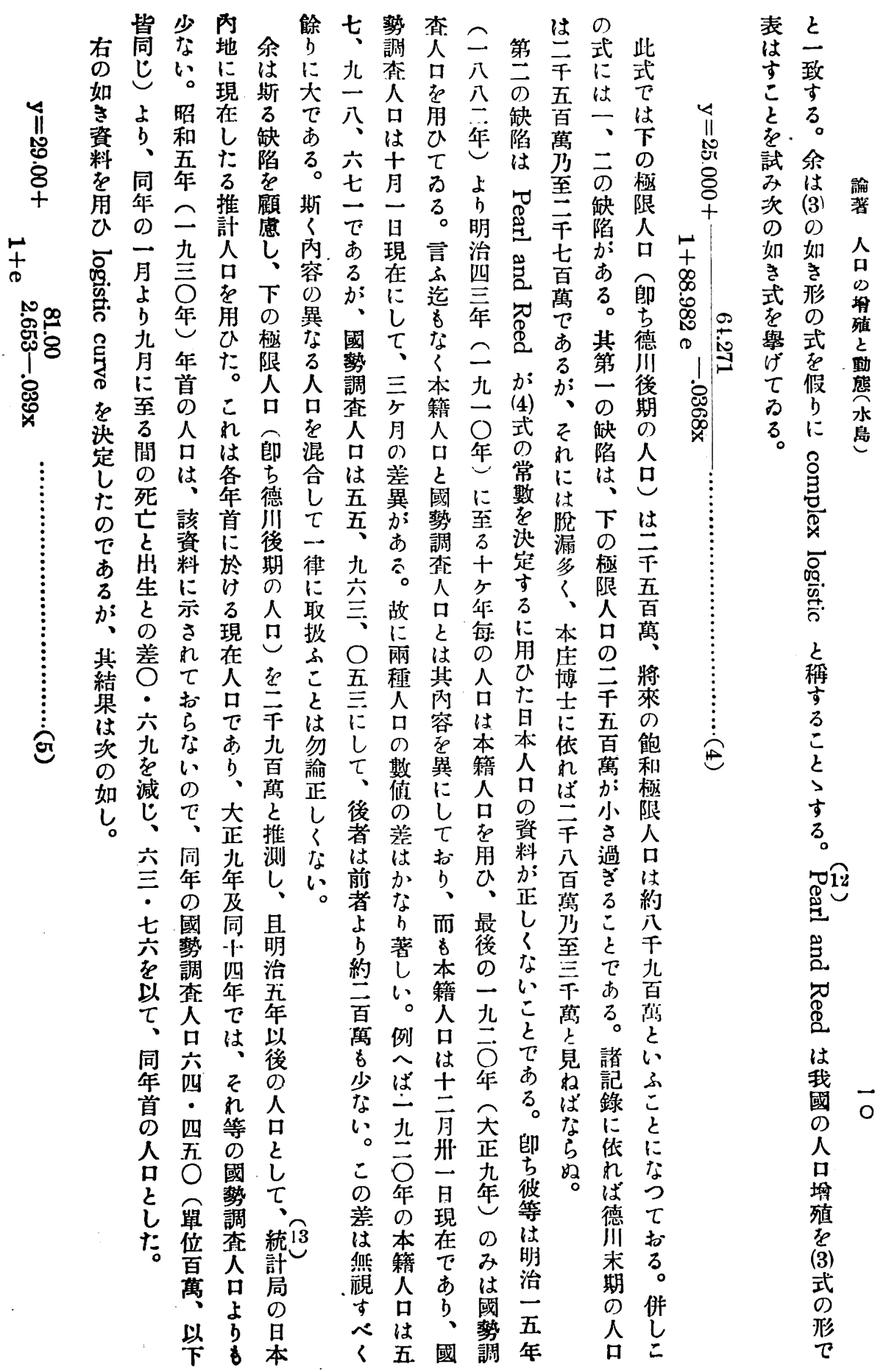


第二圆 日本の人口抬殖曲線

右 但

の $ᄉ$

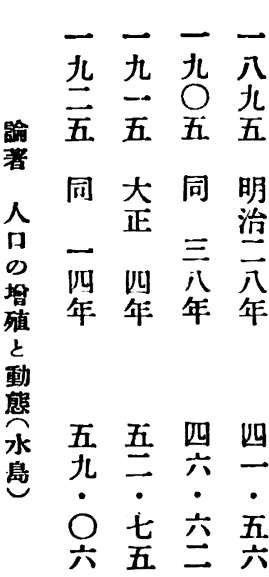

五五四四

九三六一

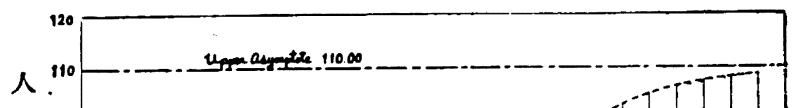

式

四四五它

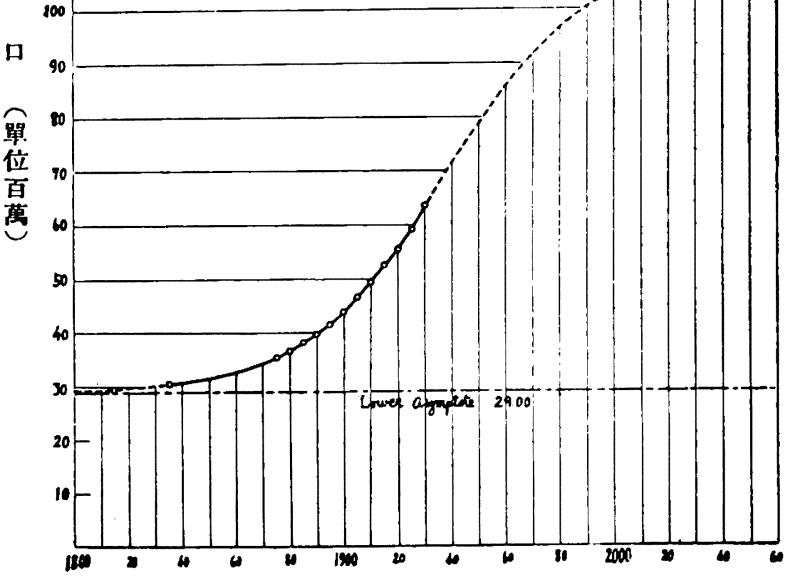

$\begin{array}{ll}\text { b } & \mathrm{y} \\ \text { b } & \text { の }\end{array}$

計 單

算 位

し は

息

五一五

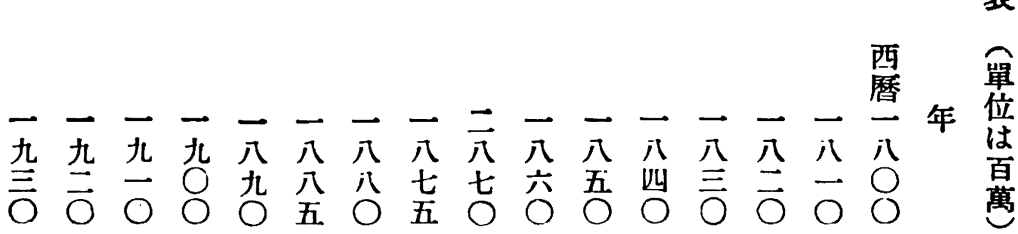
는

照大同同同同明明萬嘉天不文交䔈次 和正治治延永保保政化政

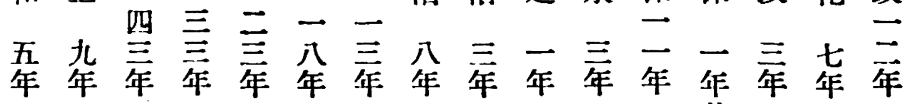

六五四四吾分交吾

此
留
○
○

表

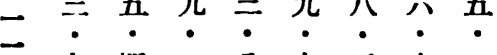

六坚公五昆公六

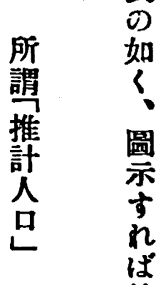

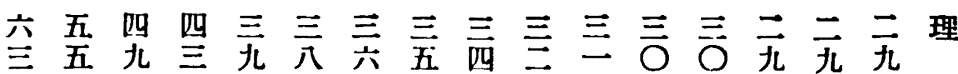

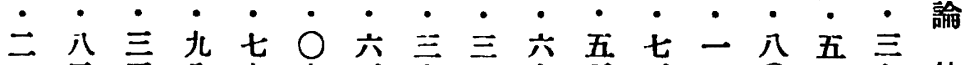

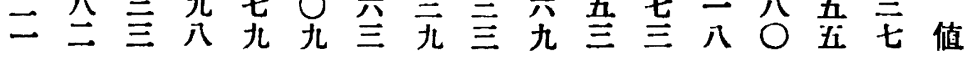


III卷 430

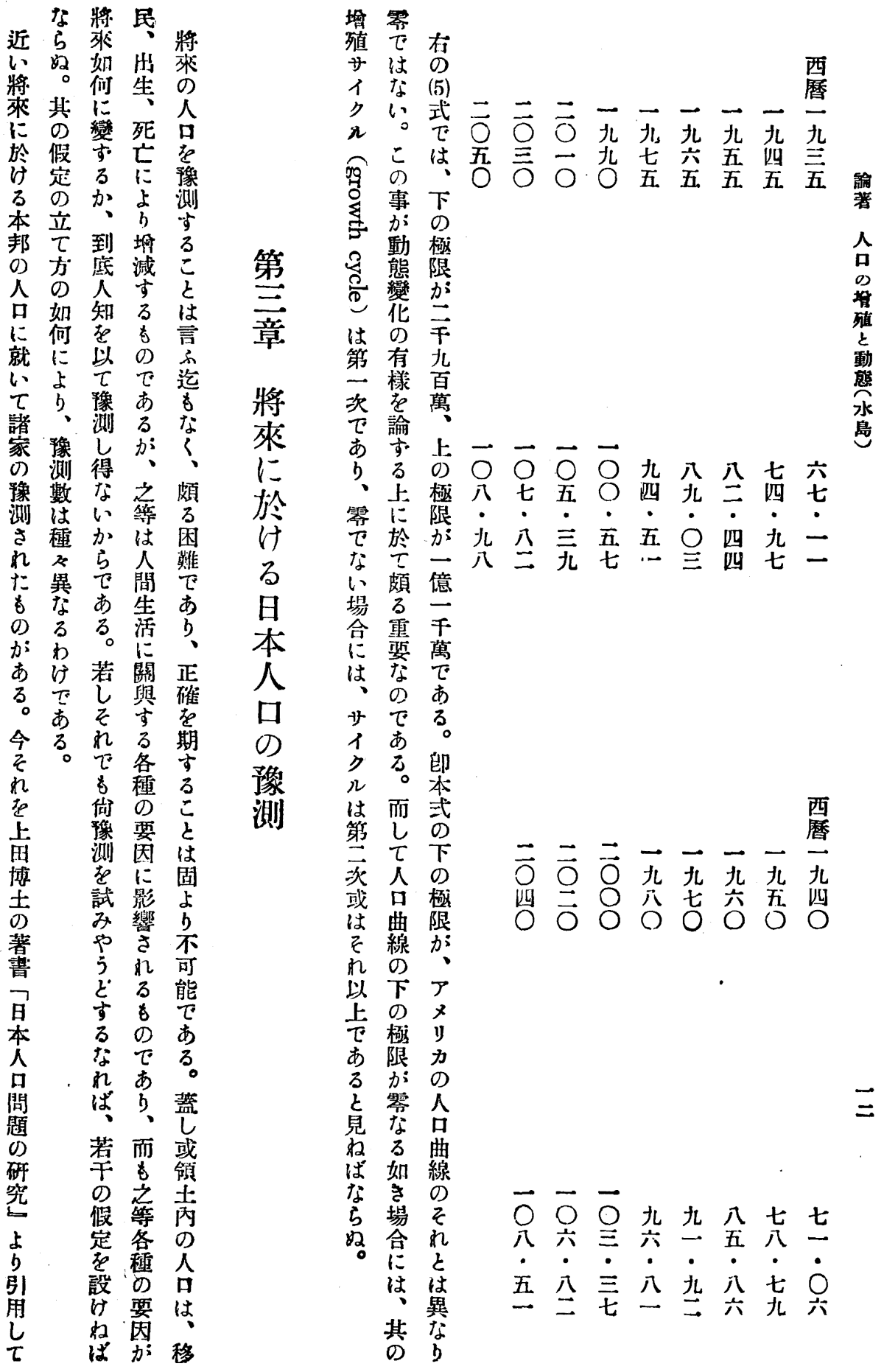


II 431

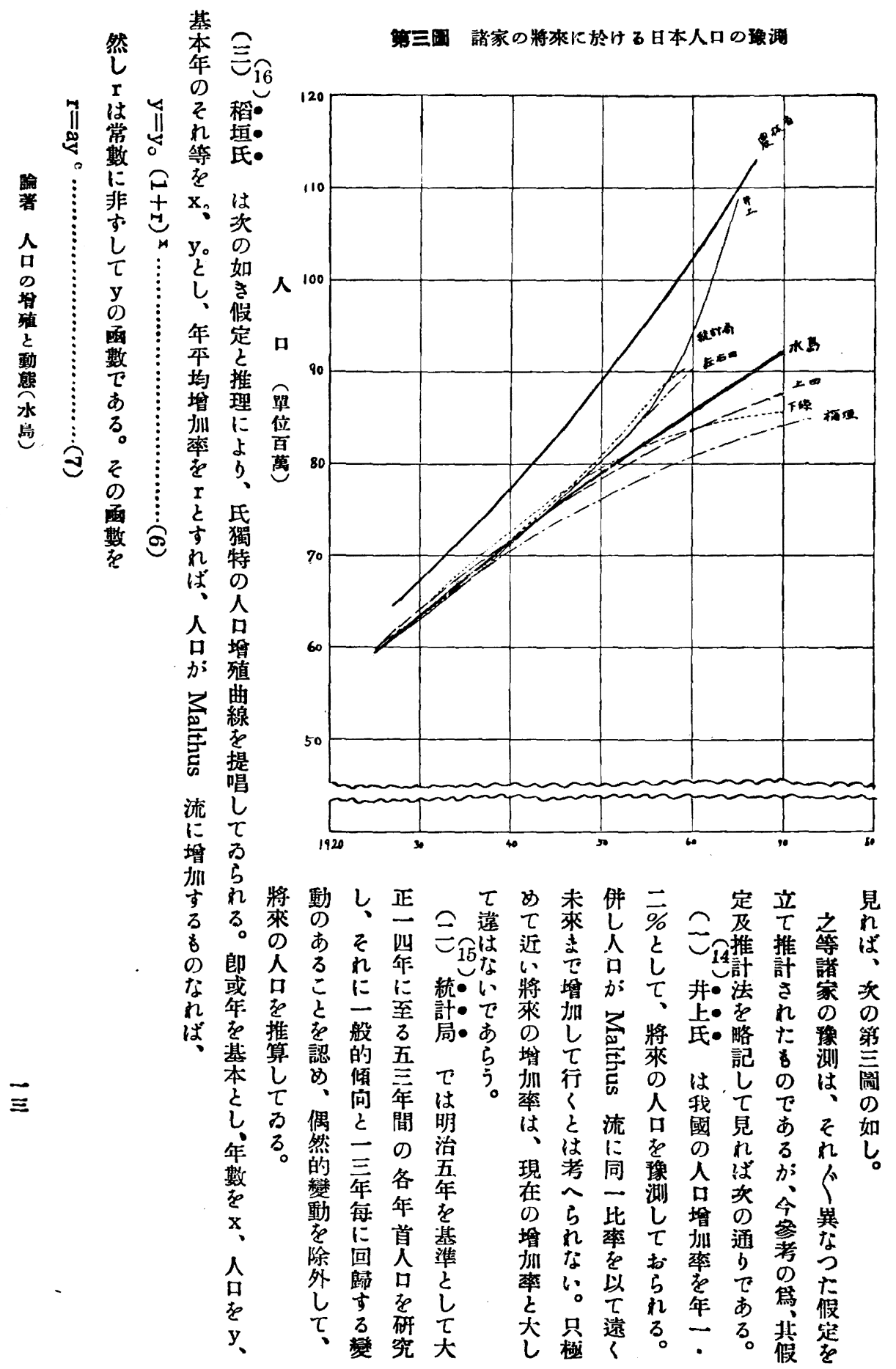




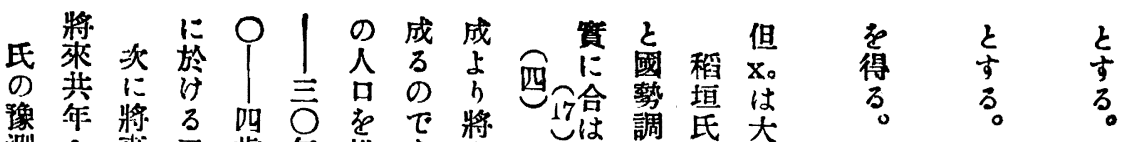

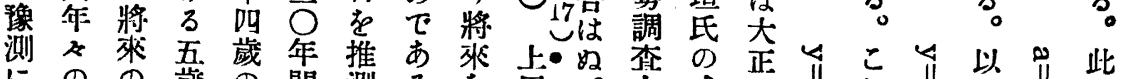

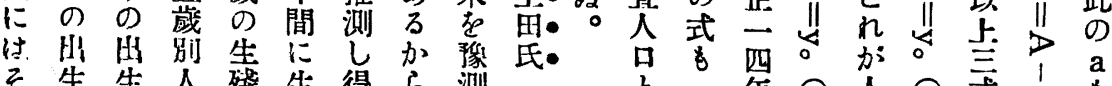

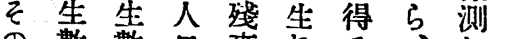

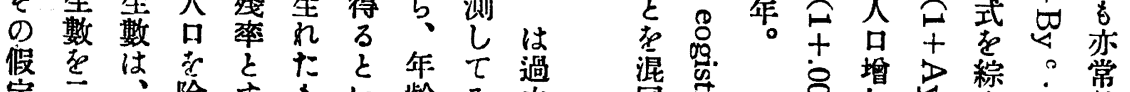

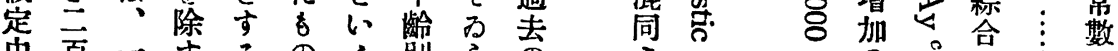

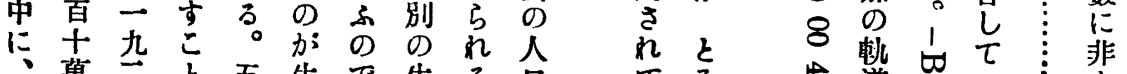

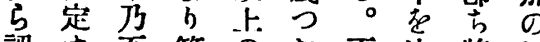
認重至算市た而決獎倾 め。二出告のし定來向

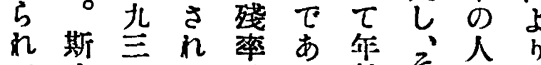
斯三れ舟 क作之人

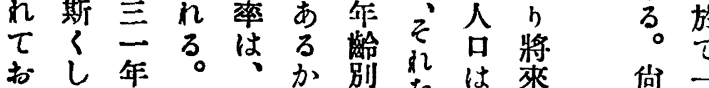

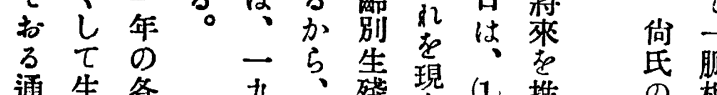

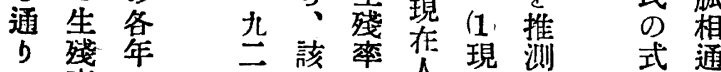

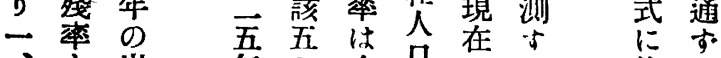

$\therefore$ 出年万次品分依了

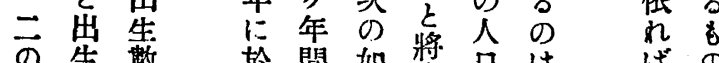

弱政 整

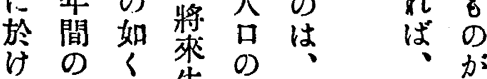

點通出出生丽少德

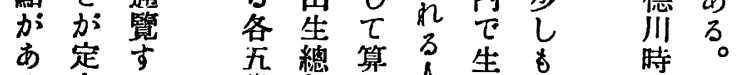

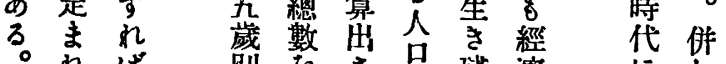

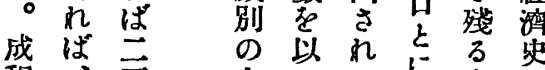

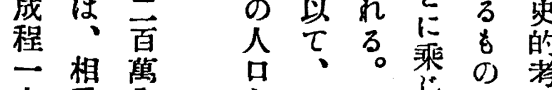

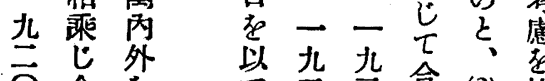

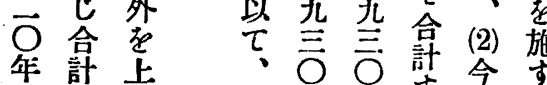
筟訫卡各年年主含志

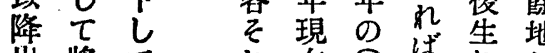

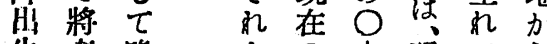

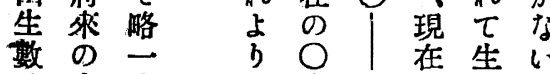

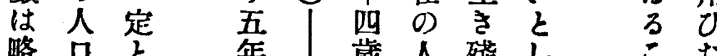

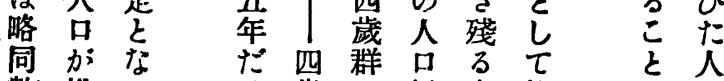

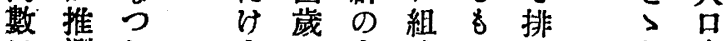

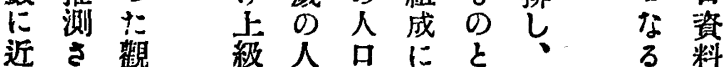

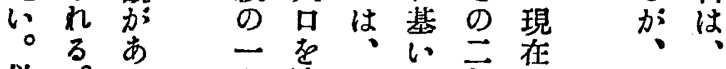

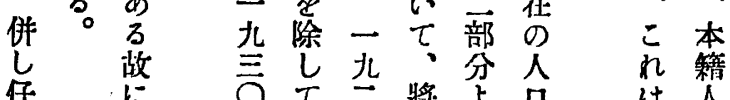

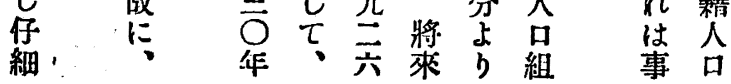




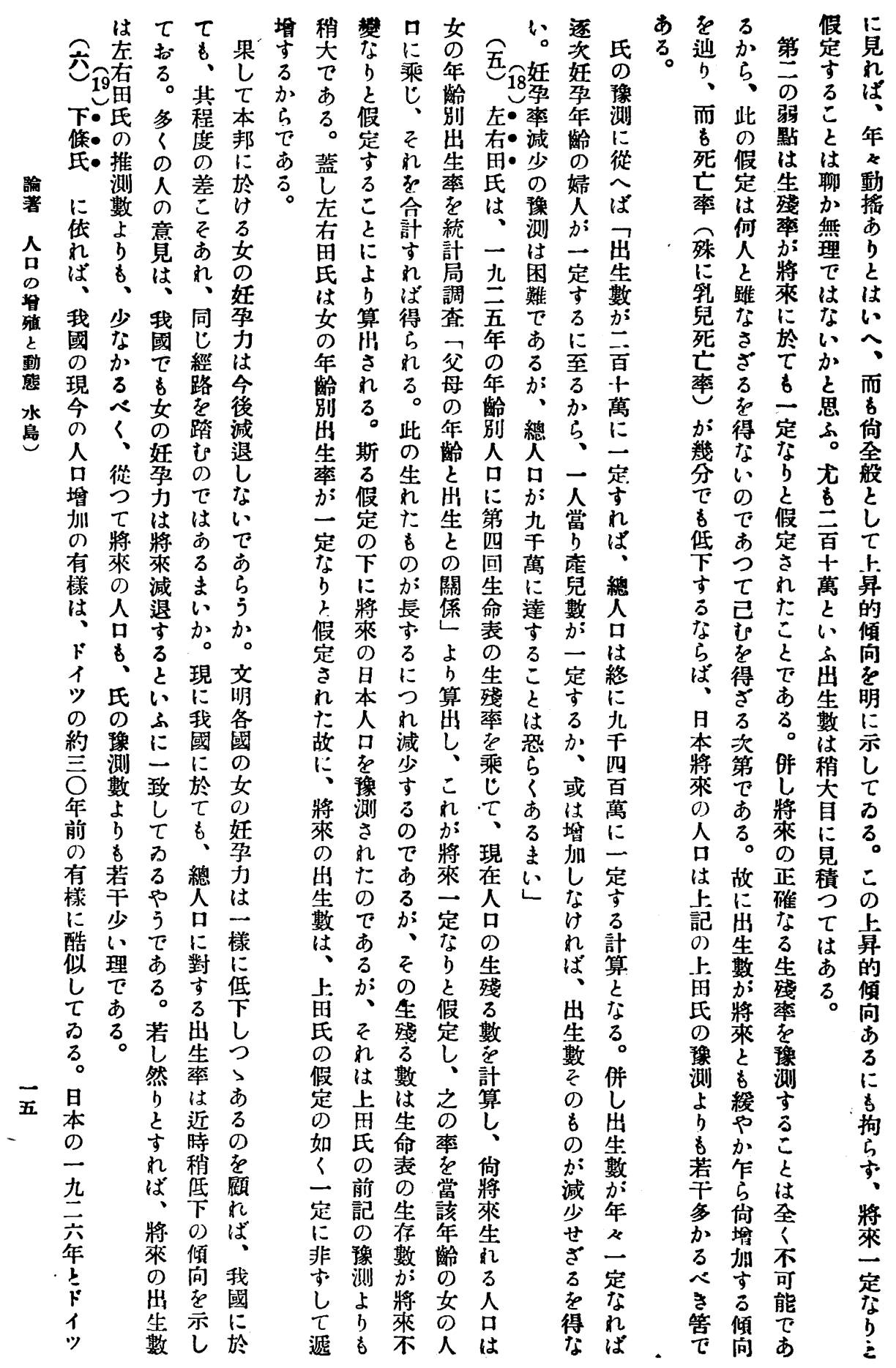




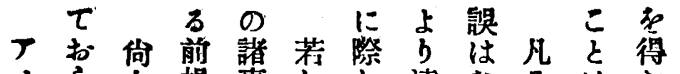

メら人提事しし遠なそはた

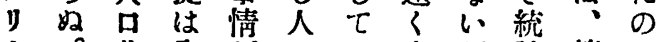

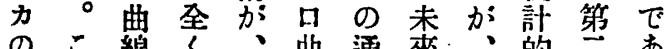

のこ線く、明通來、的策

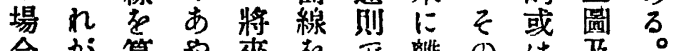

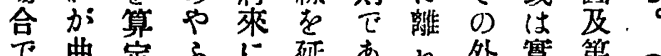

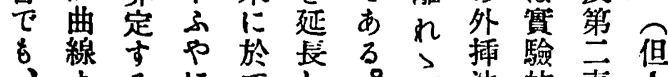

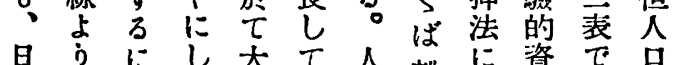

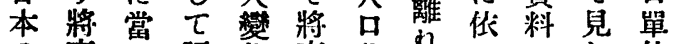

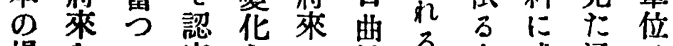

場をて容をの線るす或通は

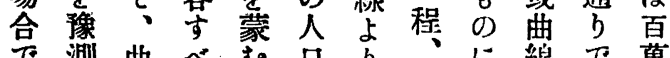

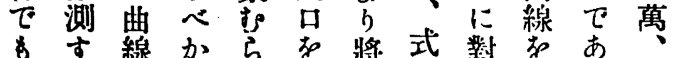

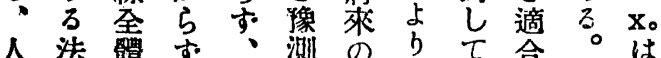

口告を過せ人算は弇然云

埥通形心去ん出心立八

加有をふにと的し大めば七

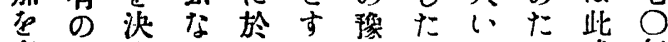

表弱定れ宁了測理にる式年

は點吉は働なる諭或場よし

すてろい試储心合り此

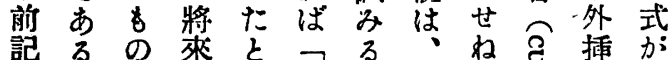

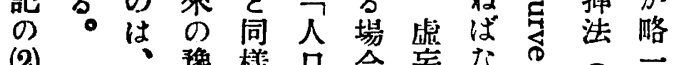

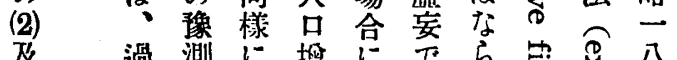

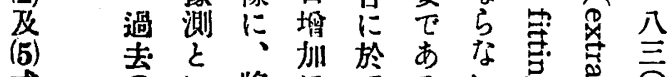

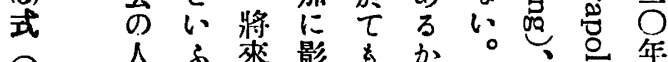

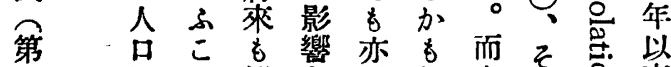

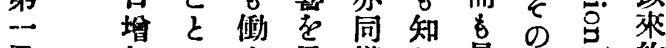

及加は年樣れ最內約

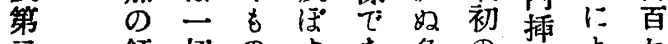

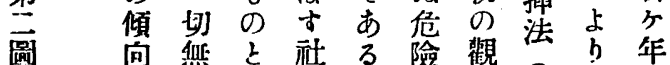

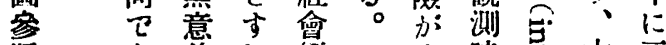

照 あ義れ經 大時劳本亘

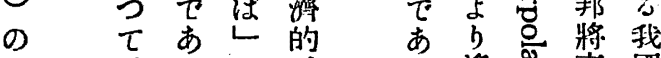

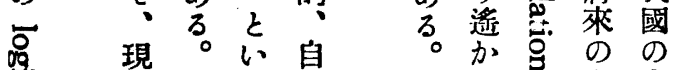

䆟充然こに巳人人

号一前環湖に只口

¿吕提境事了依垉

离

は成直人沉或值し有

は 類 は得

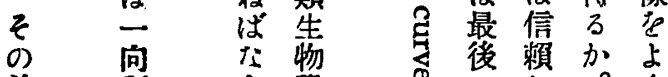

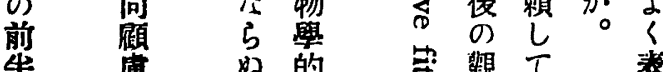

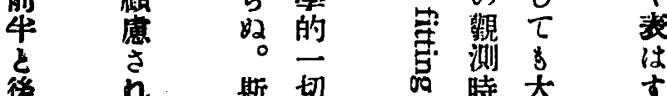

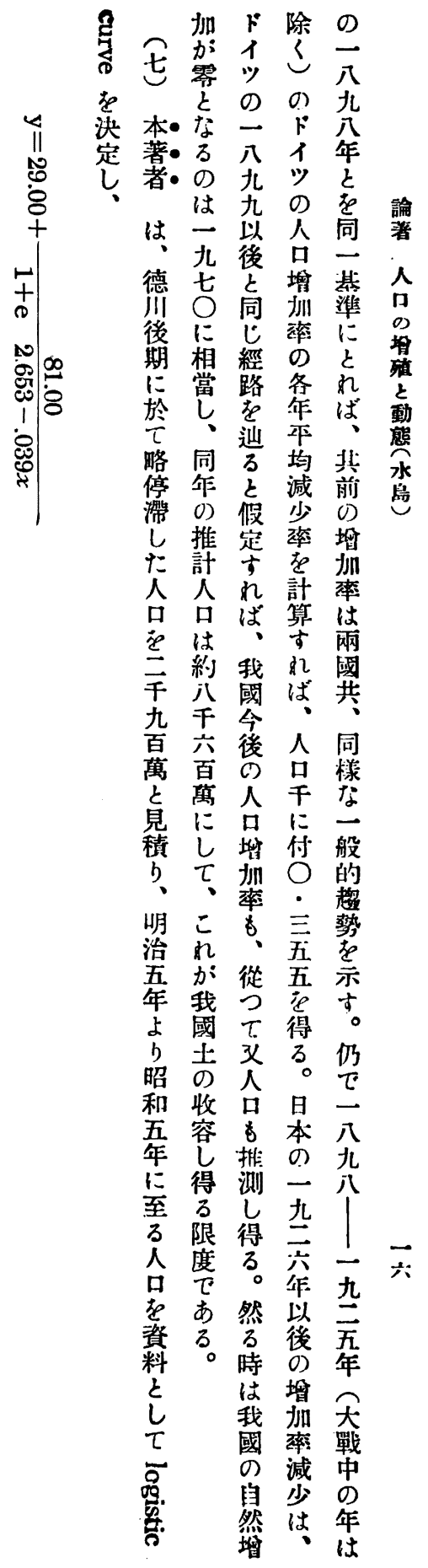


若藪夫

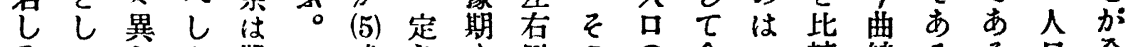

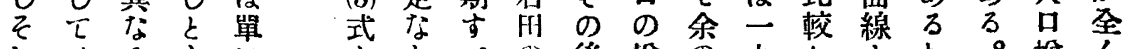

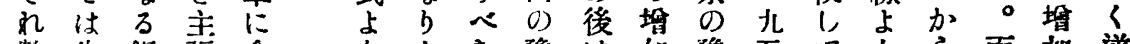

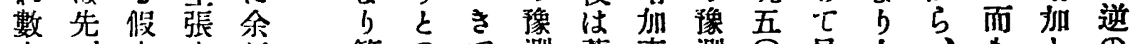

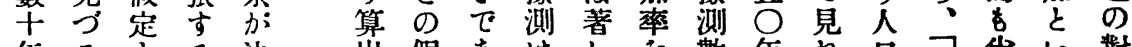

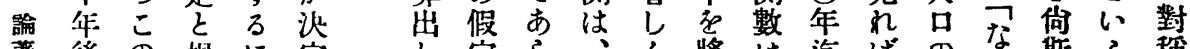

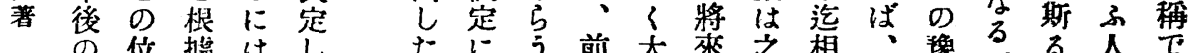
人 余售握

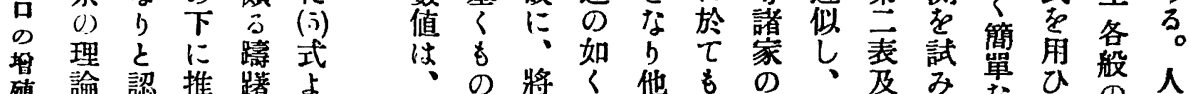

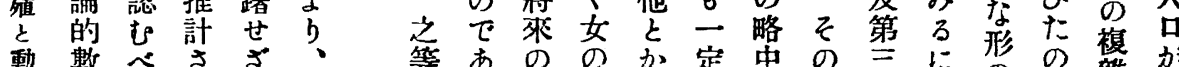

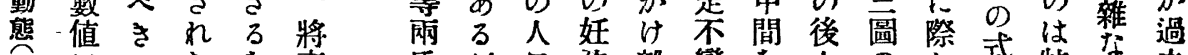

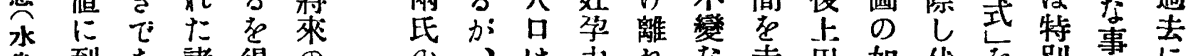
岛到あ諸得の 0 、は打れ走前如伏芷別情に

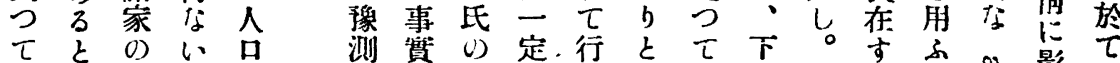

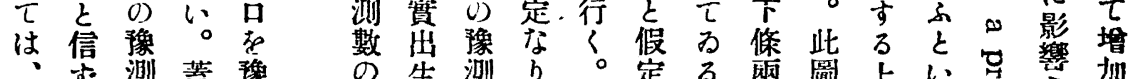

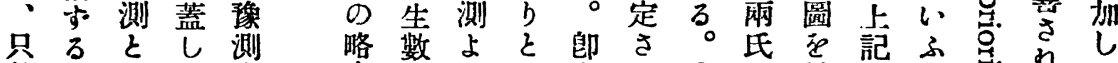

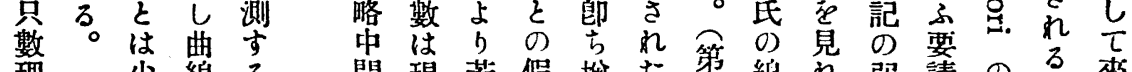
理 少線る 間現若假㙫た第線设弱請の方來

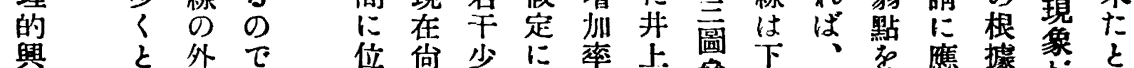
味专抙 あ に沂法つ 㱑獎 吉獎 は ら 、に述た强傾と市をは

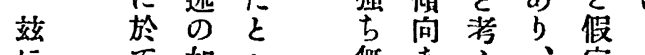

に元如

放はき式

$\tau$ 相弱

豫近點過

せ し必察事

欲而的賽

袋略良

万衫在交

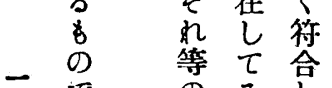

齐守 あ 將

余方荍來

豊品僧

線䅼他尘

热あ謀方主念

な故吕れる 約

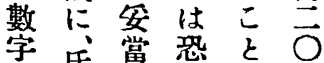

で氏密它は年

は豫あく稍間

な豫ら長䅣溒

察少又䐓嶈根

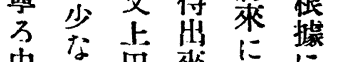

慫

中逈界來はに

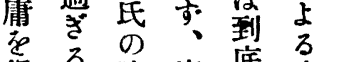

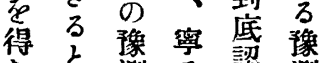

た自测若容

す

は导嵌降立近

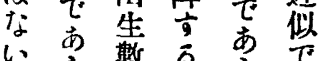

上に他

曲讦念に方し向

て 测のな

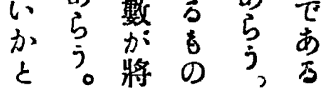

向れ諸

及他家

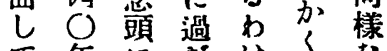

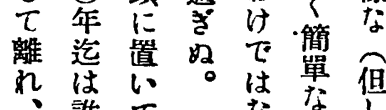

左

田测式將正 昰

氏 6 策し 經

井似將何軌路

上莱策迹迹

氏 お

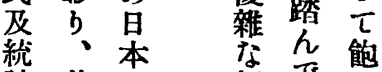

訫其余綎行和

の稻蛋灾

测坦算 巡

數 0 ᄂ 㔔莮行

は線之会方く

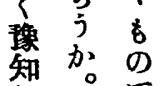

ᄂ

测のな

の

得頗 


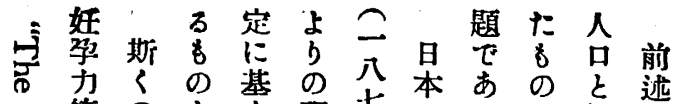

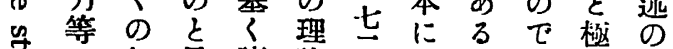

司如兒諸諭年あか; あめ如

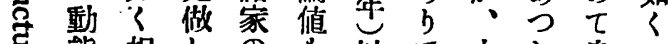

能態相しの宁以て少た良了

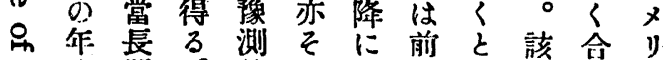

$\infty$ 次期。数のし記守曲致力

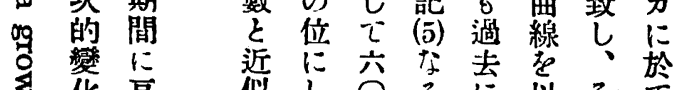

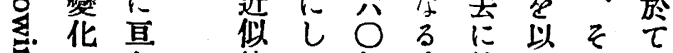

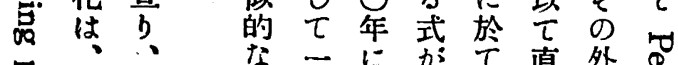

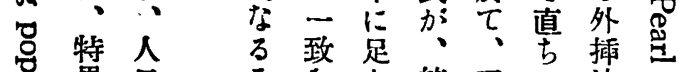

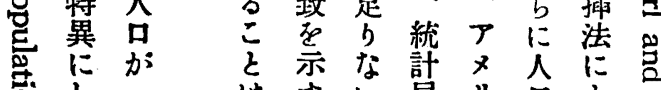

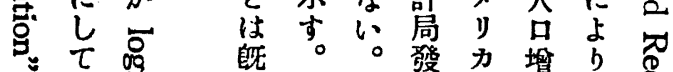

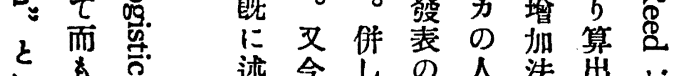

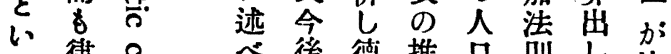

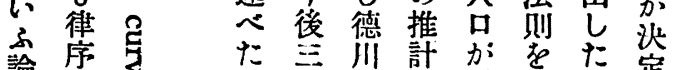

交市心 通 0 末

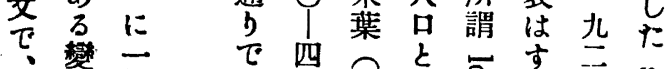

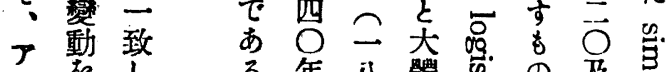

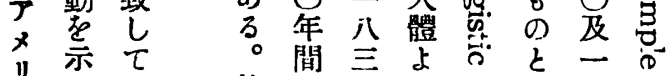

力主增 故

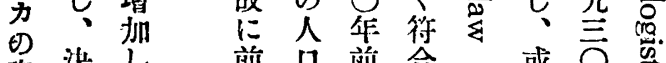

凟決し 前品前命に或 年号

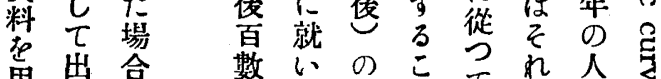

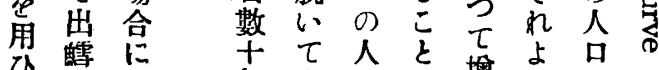

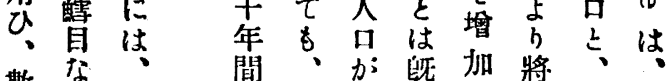

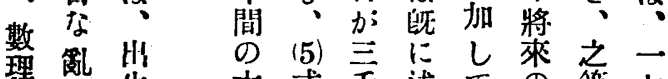

的雜生本式手述元 等 七

にな率帮占萬心來人少年

第 篩

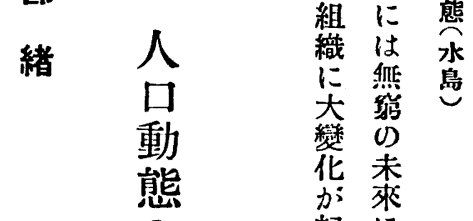

論

前

に

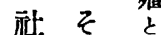

會机動

組に息

に留鳥

継

起

る 達
方杂

あ す 口

う。 億

质

完 萬

了杼

万限人

か吉

次

棃㘘

人 理

間

生 あ

活

大 :

調緢

方

來 只

行數

ば理

そ卡

0) 6

時 0

にに

は し

别 勿

個 諭

の暧

畤言

岕な

腟

先

開

始 顺

す 線 


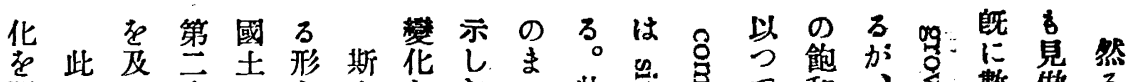
訅 些 ほ

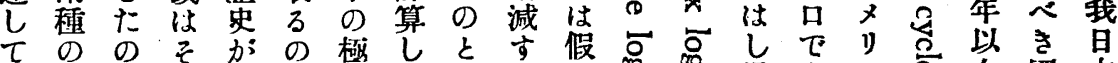

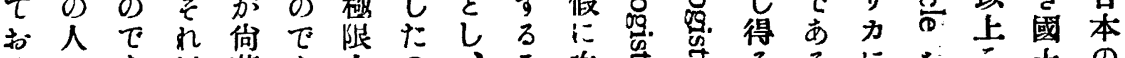

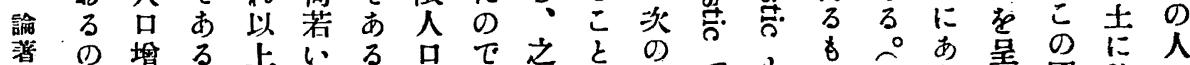

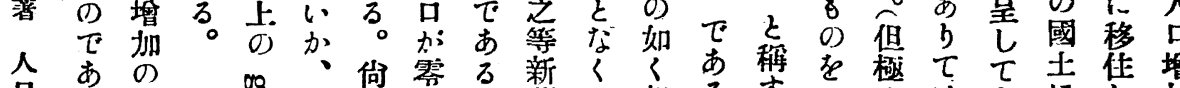

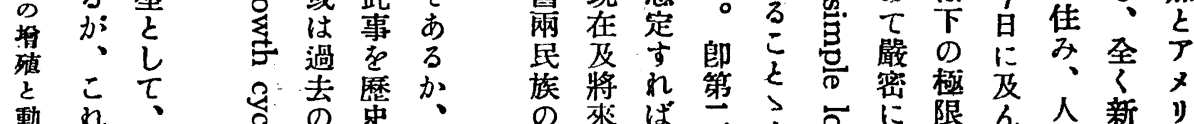

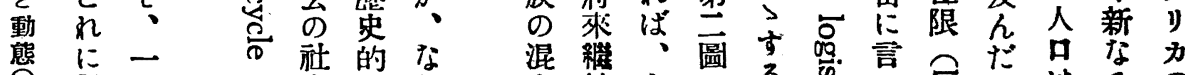

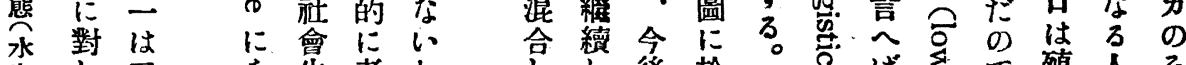

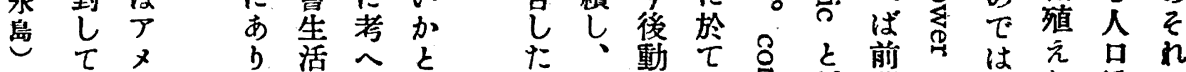

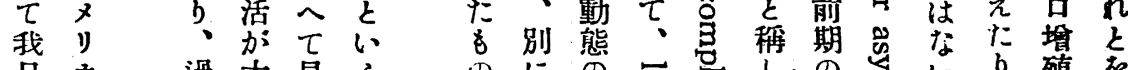

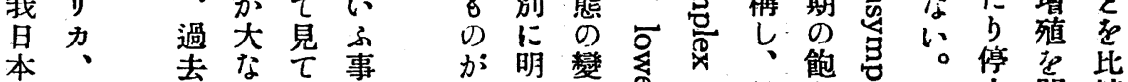

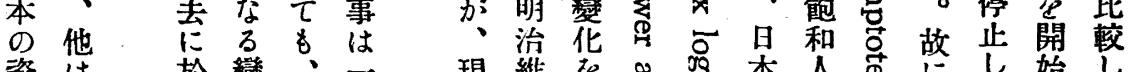

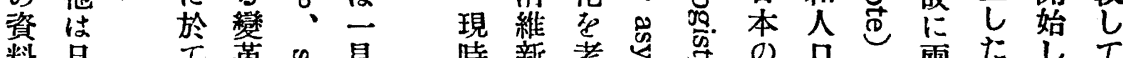

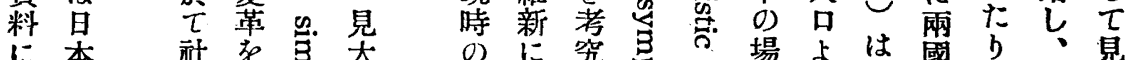

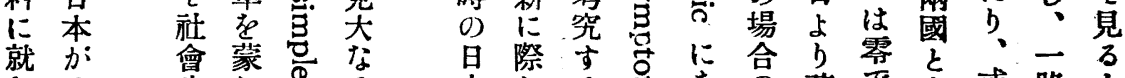

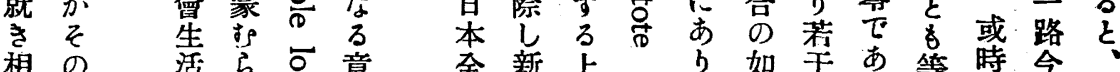

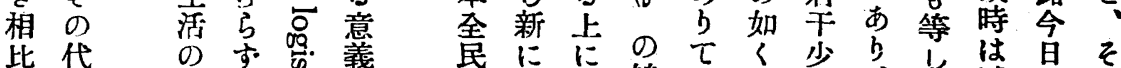

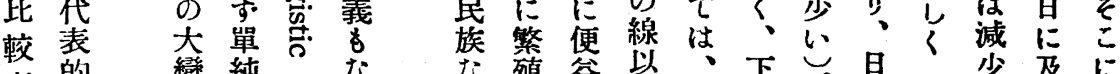

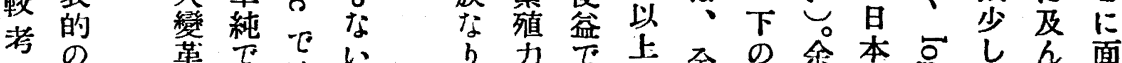

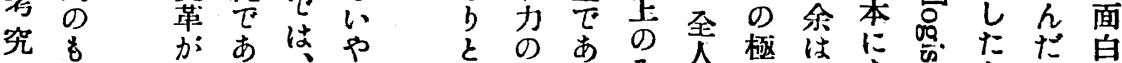

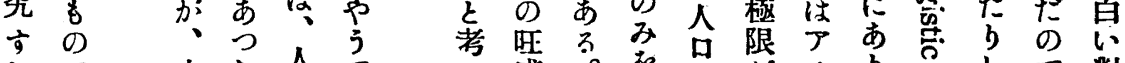

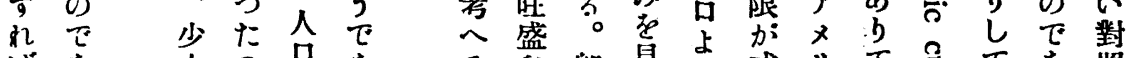

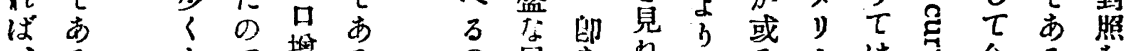
人。

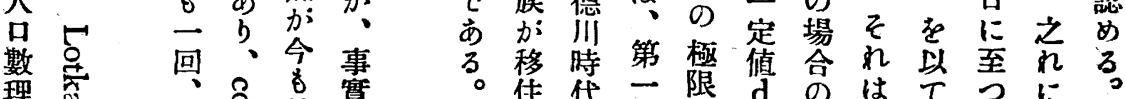

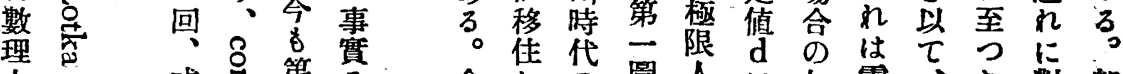

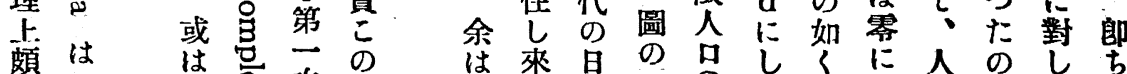

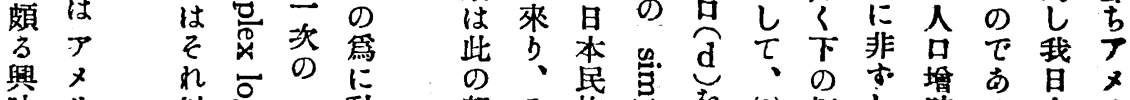

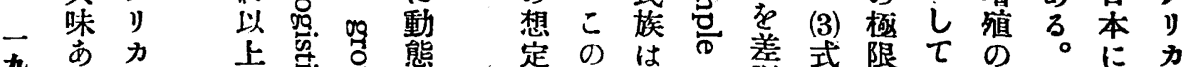

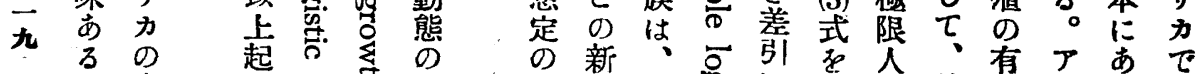

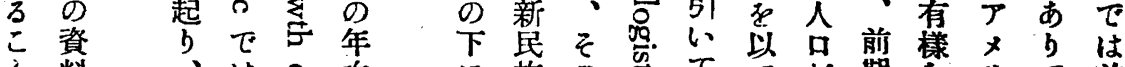

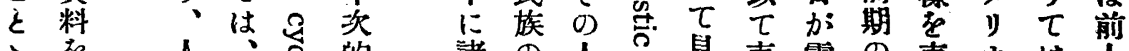

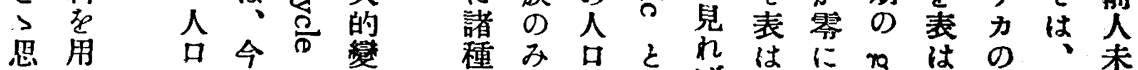

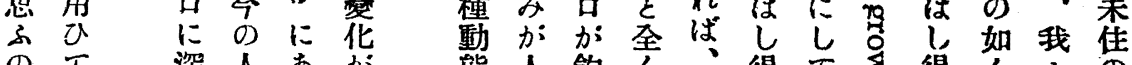

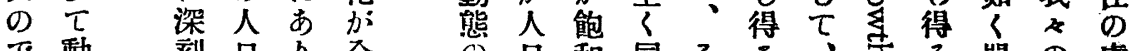

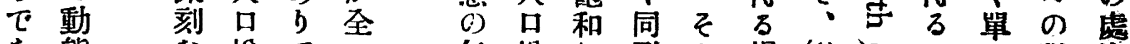

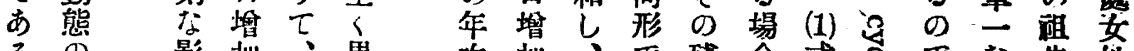

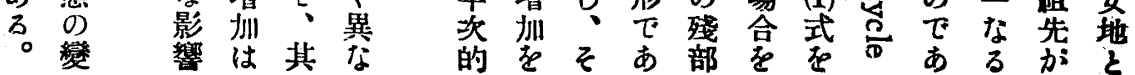




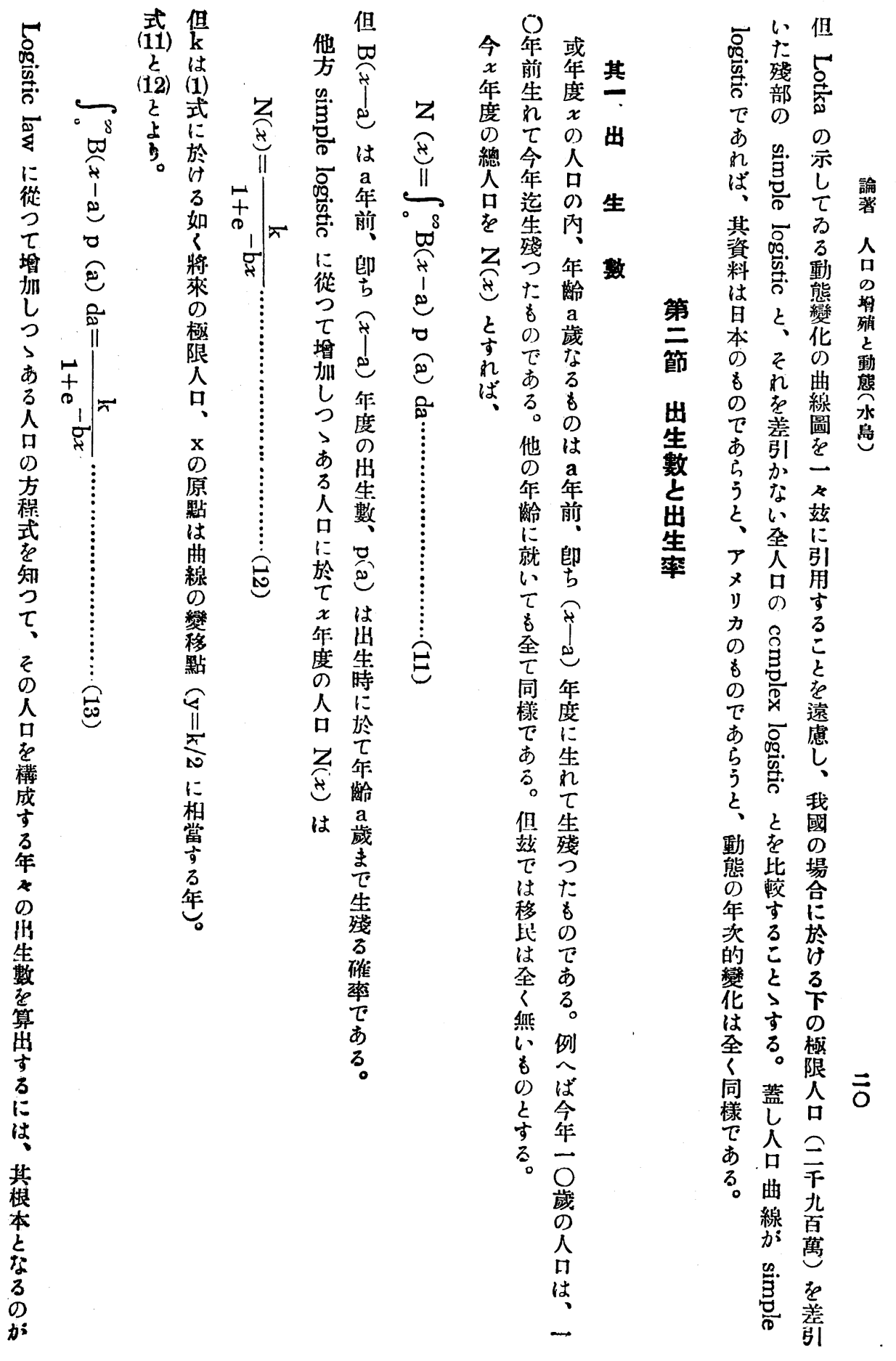




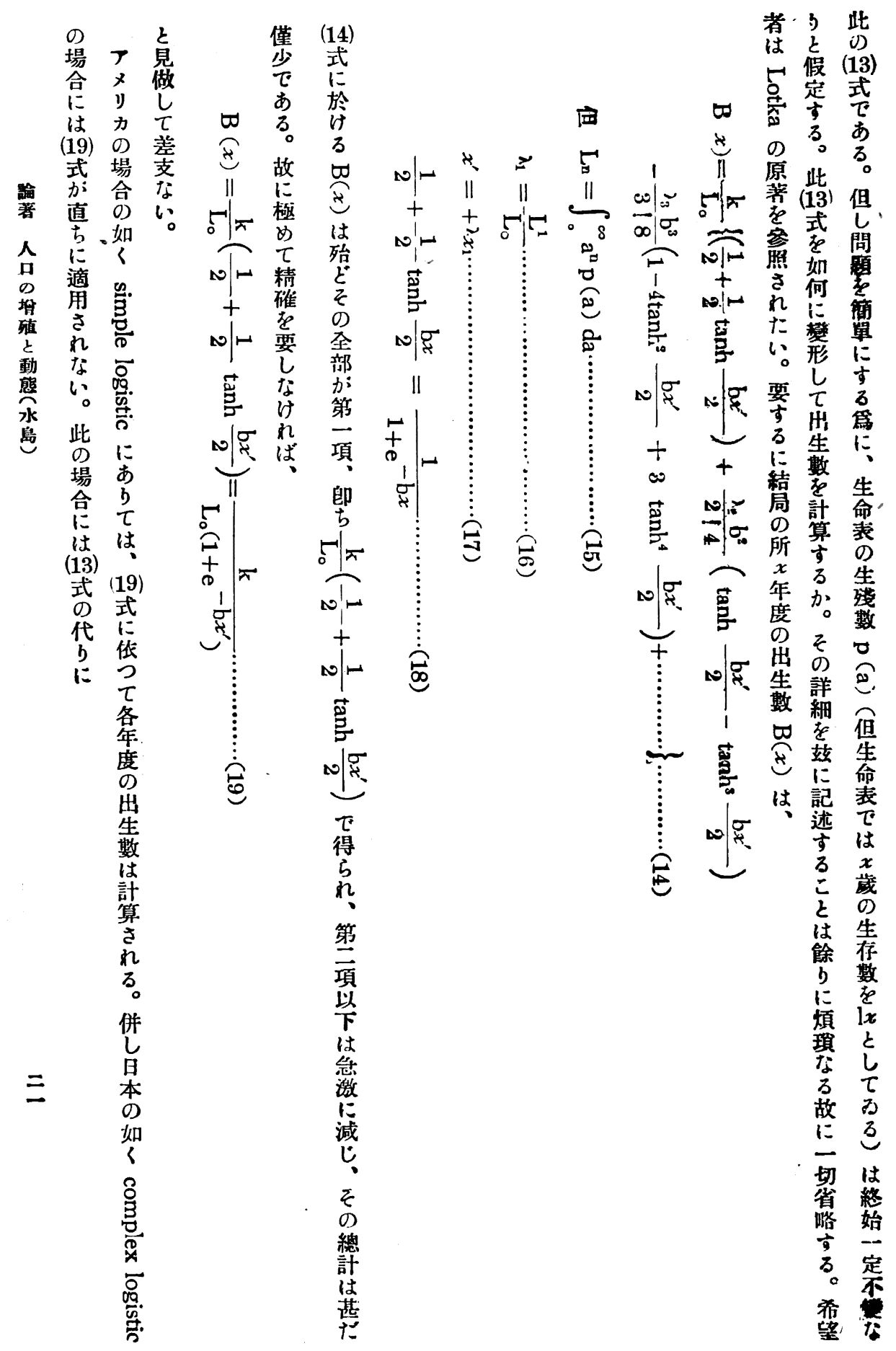




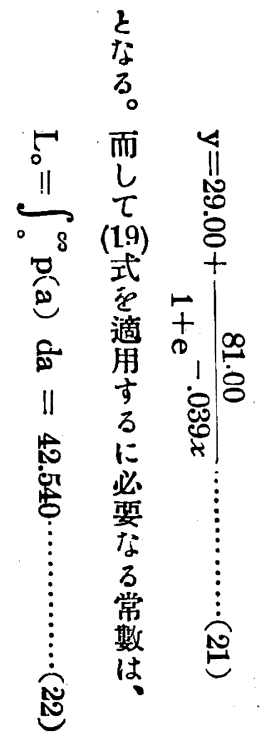

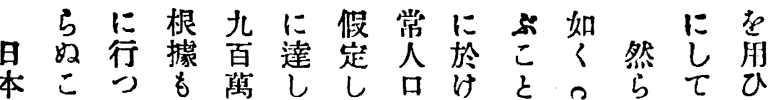

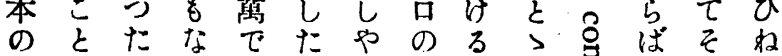
人は理いあ場う出新す召日れば

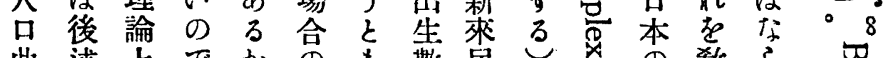

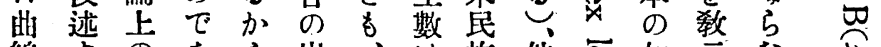

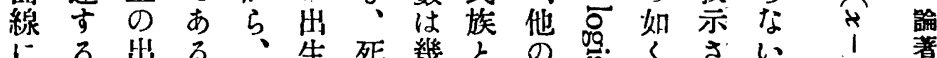

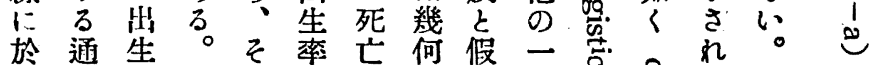

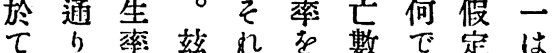

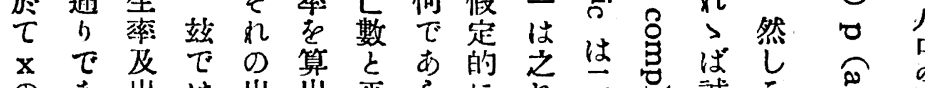

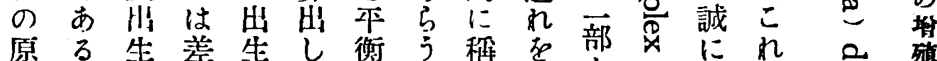

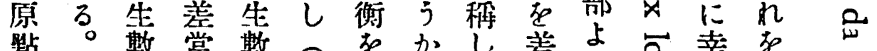

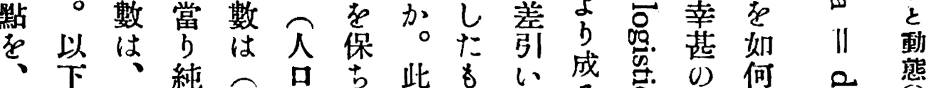
曲旦純 0 口古此

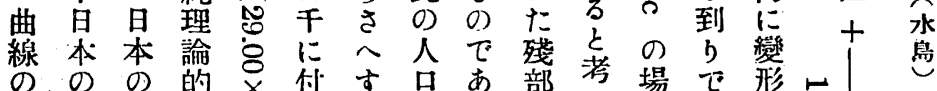

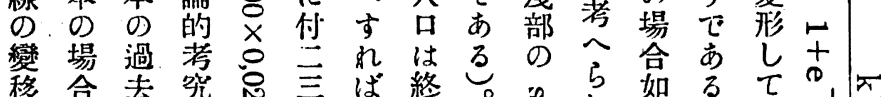

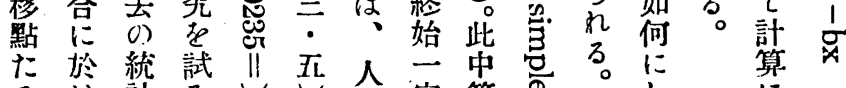

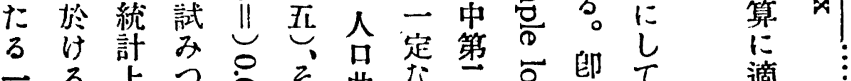

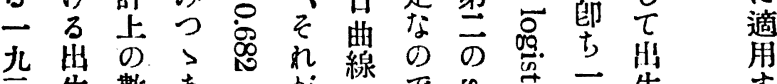

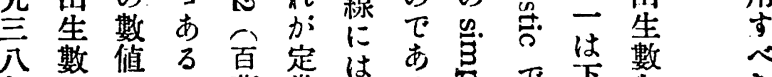
八數值 る 否定 は

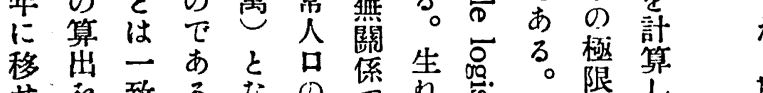

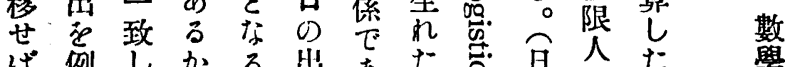

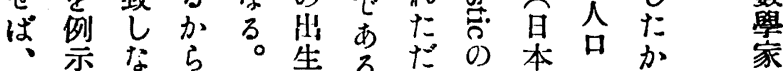

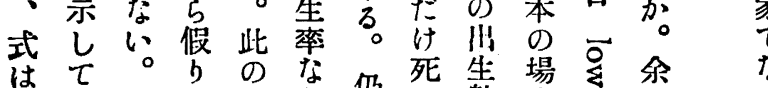

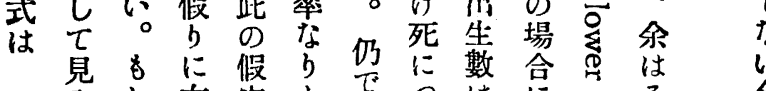
やし右䇥衣余つは余

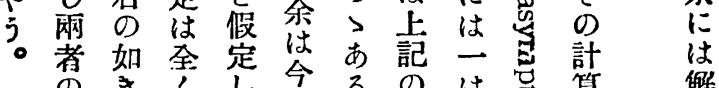
紊

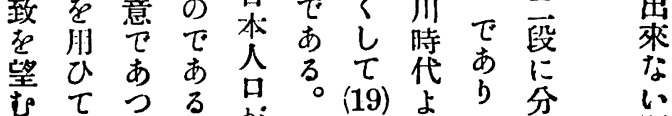

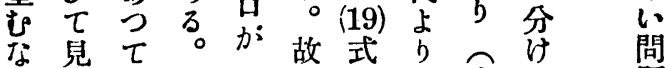

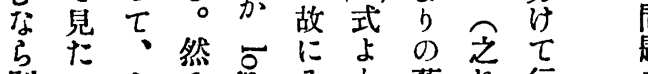

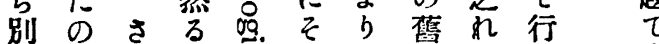

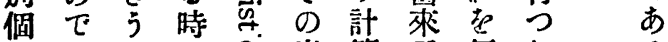
假せせに出算厎便た る。 假る。如 立の 些常

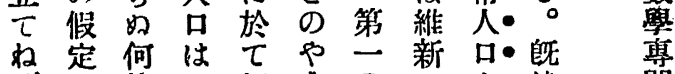
は定何は極うの 


\section{管 341}

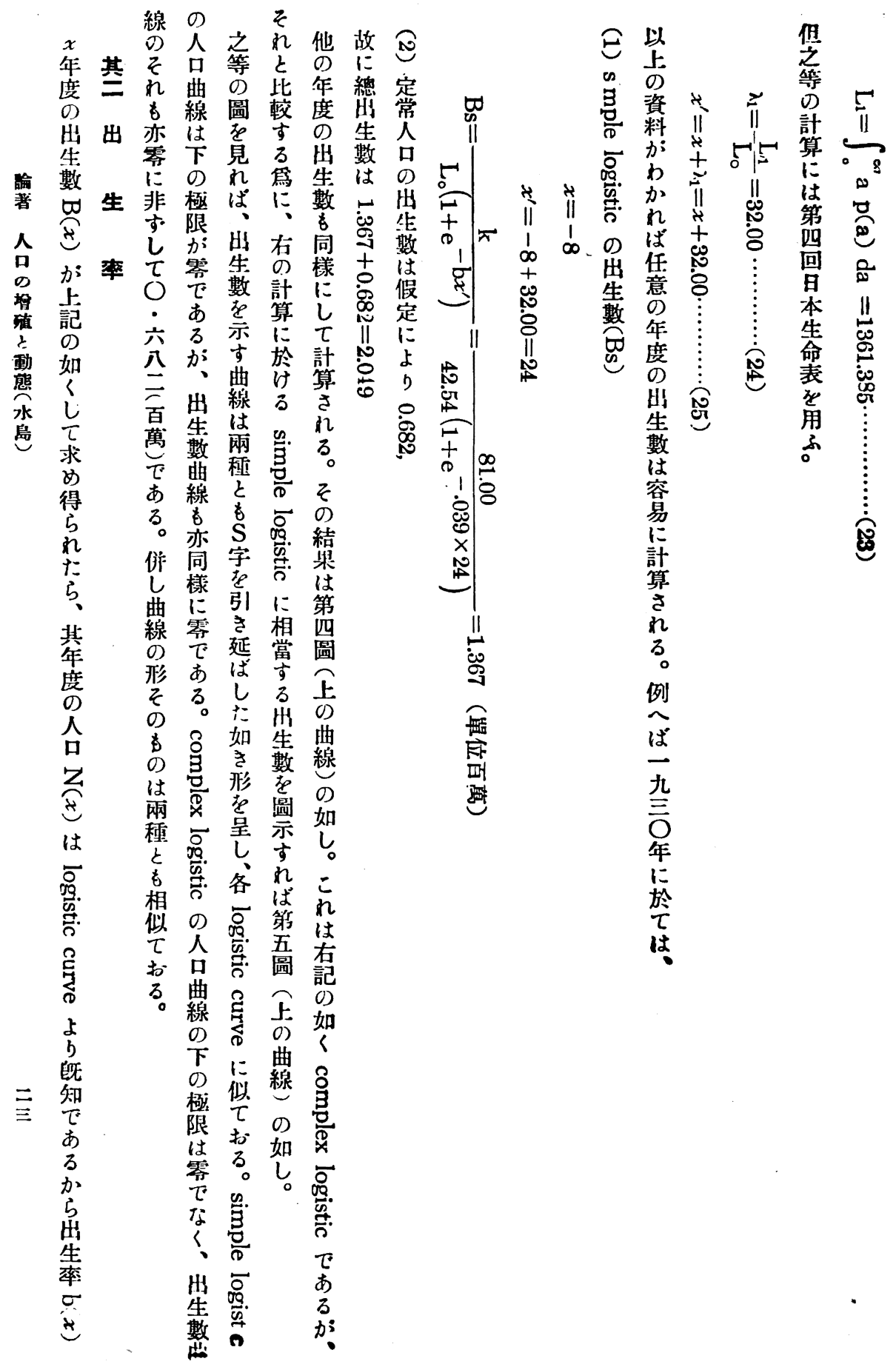




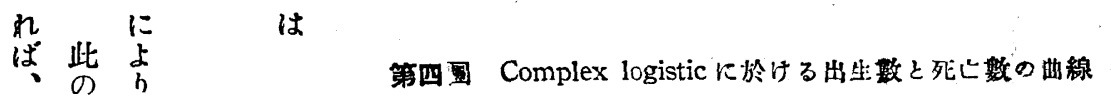

第 H 容

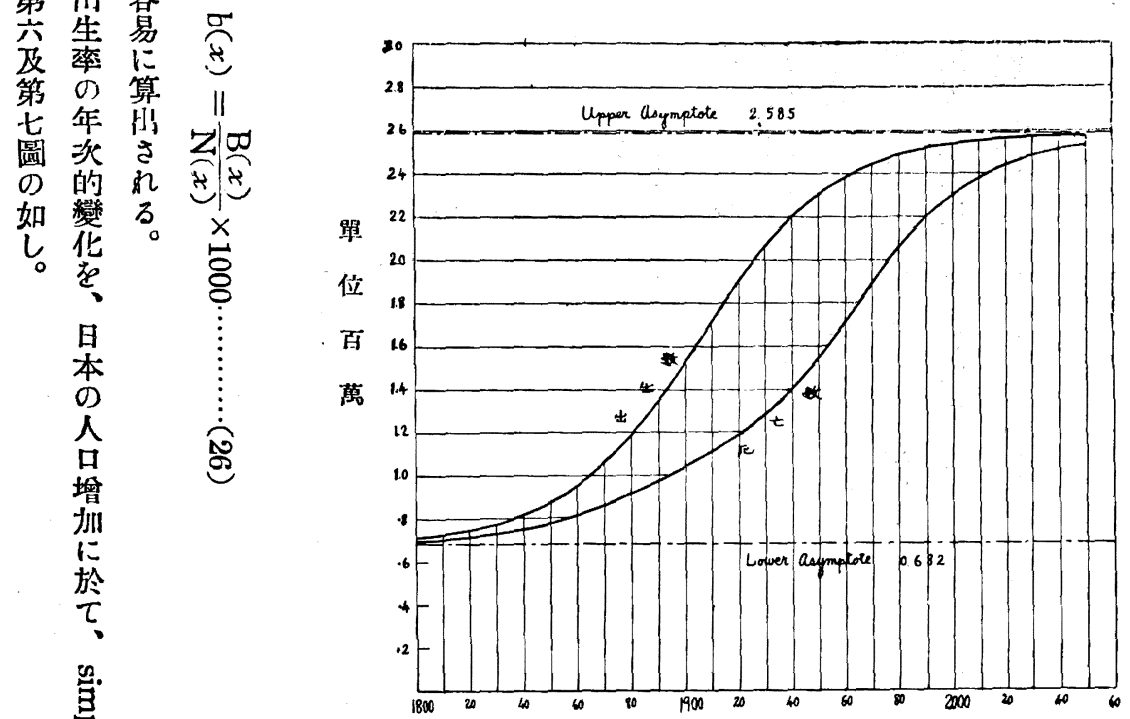

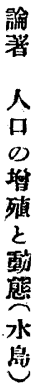

年

第五圖 Simple logistic に於ける出生数と死じ数の曲線

ถั่

દ

人

口

の

8

突

웅

疍.

$\varepsilon$

D

各

計

算

l

比

校

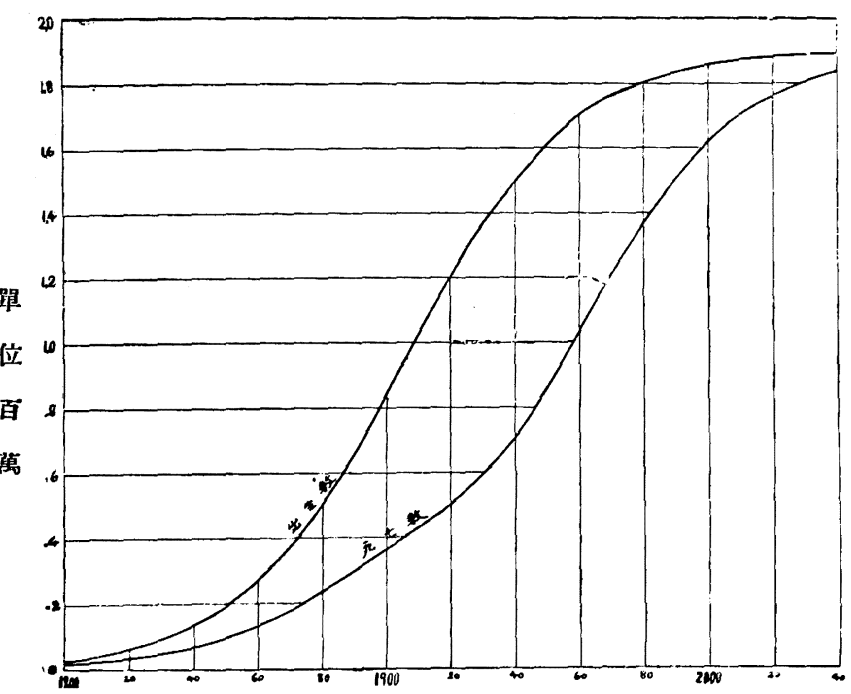

$\overrightarrow{1}$

ᄂ 拜

見 
III 卷 343

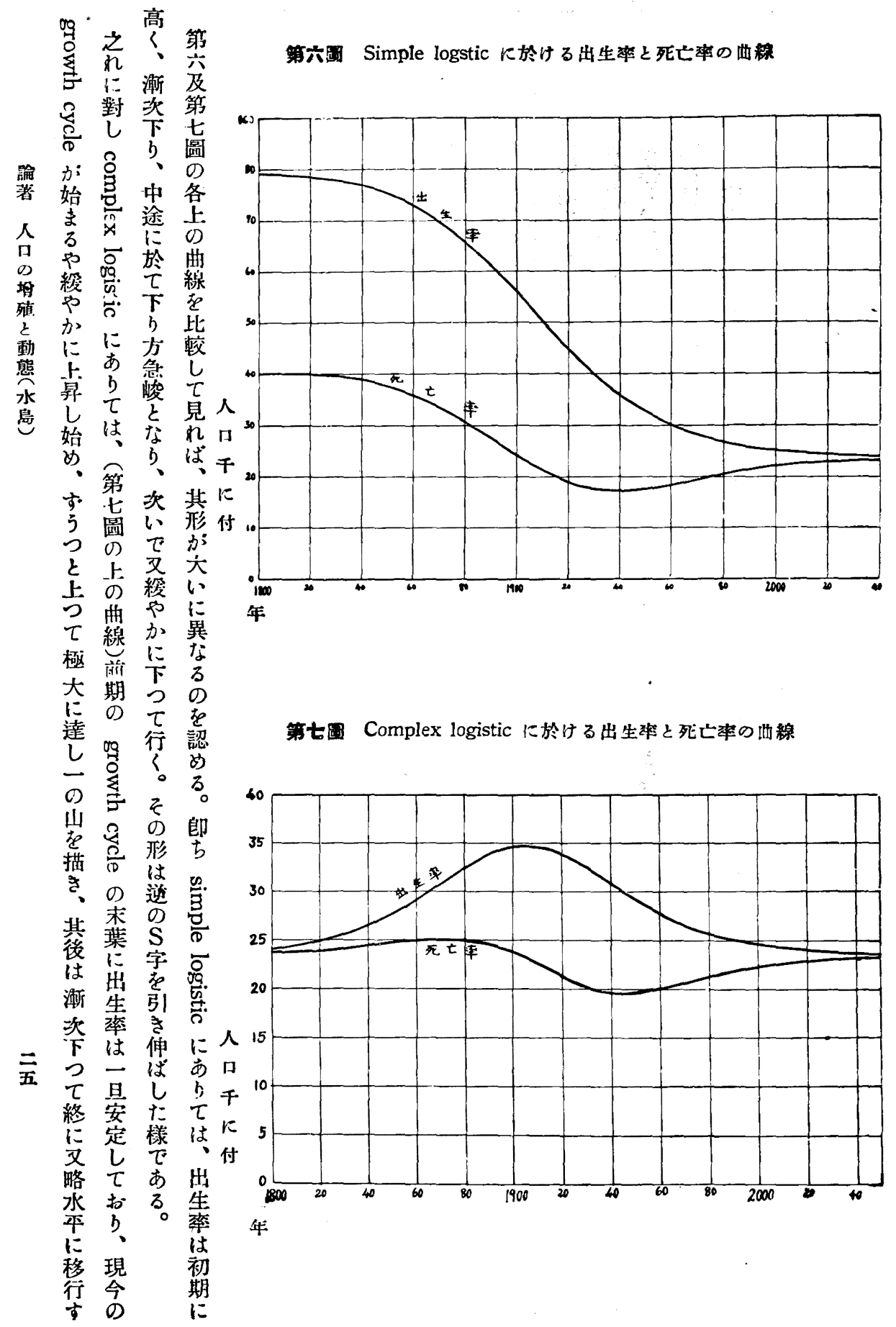




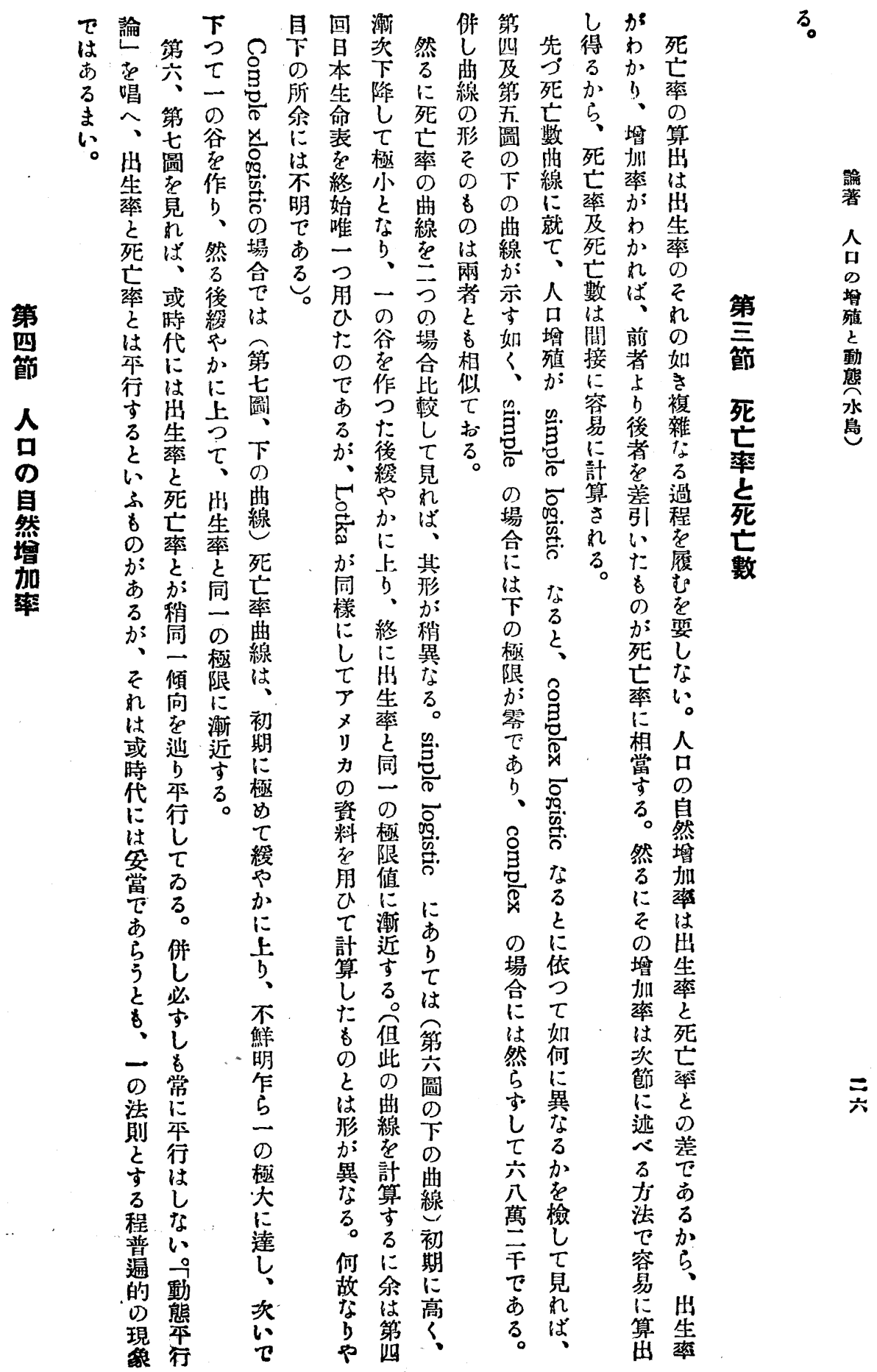




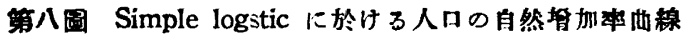

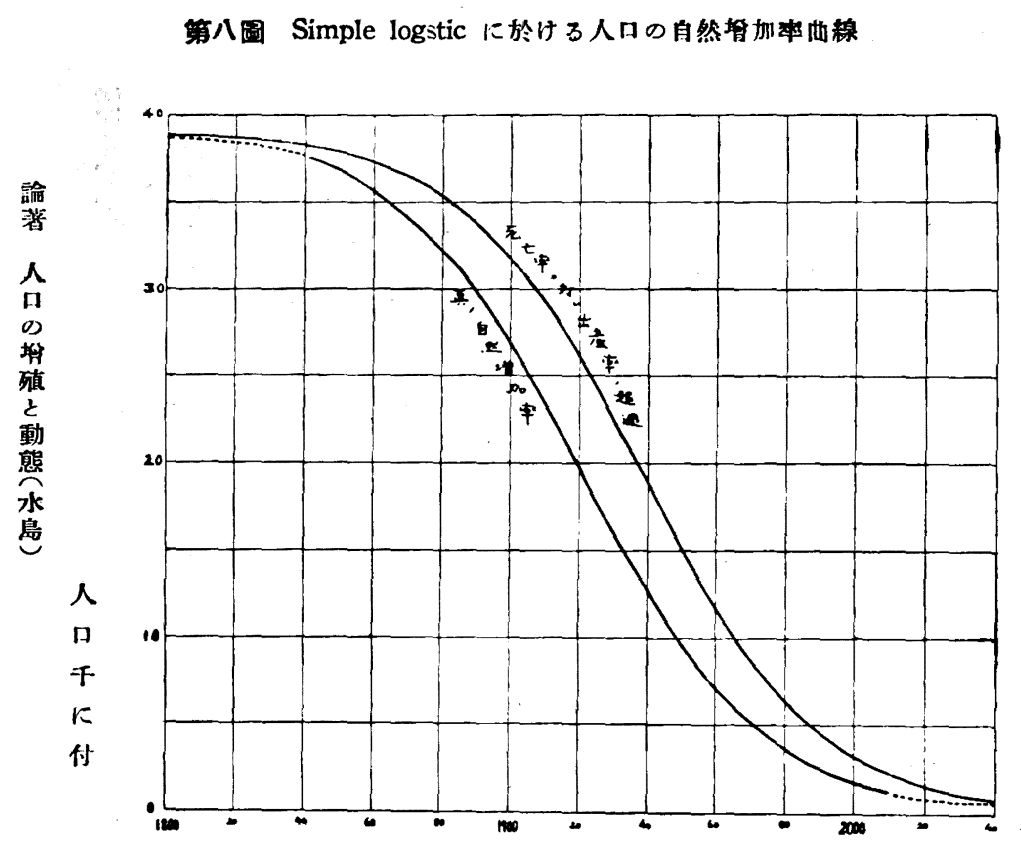

普

$>$ 道

あ ᄀ -

人只所

口自 謂

の然人

扠 加

率

は

一稱 加

人せ 新

口

千 n

$に \tau$

付

(4)

3
3
8
9
は
䔟
壱
除
外
ᄂ

第九圆 Complex logistic に於ける人口の自然指加率曲線

移

除

外

ᄂ

其

年

の

出

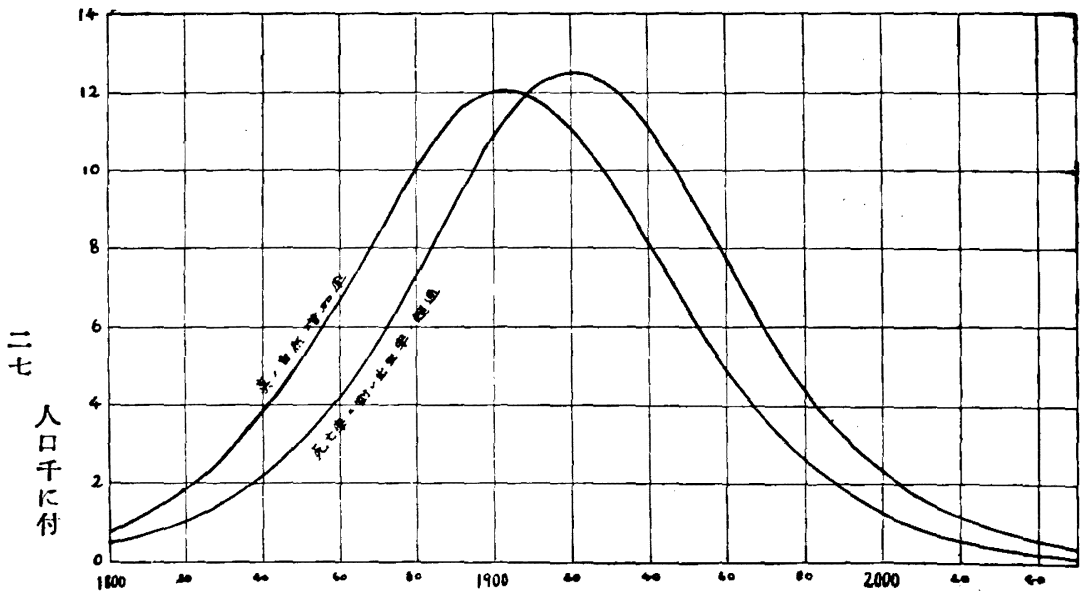

生

盐 


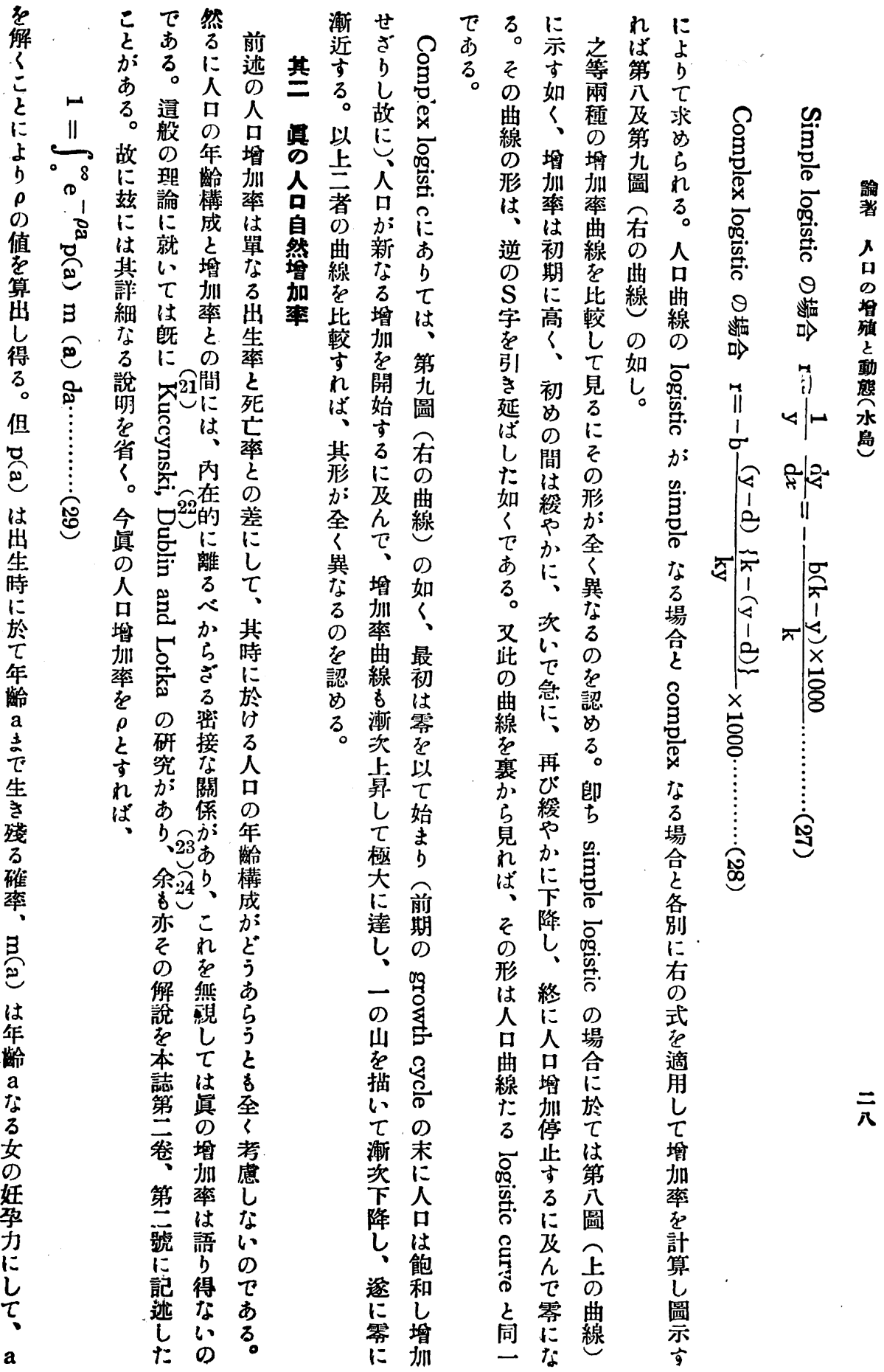




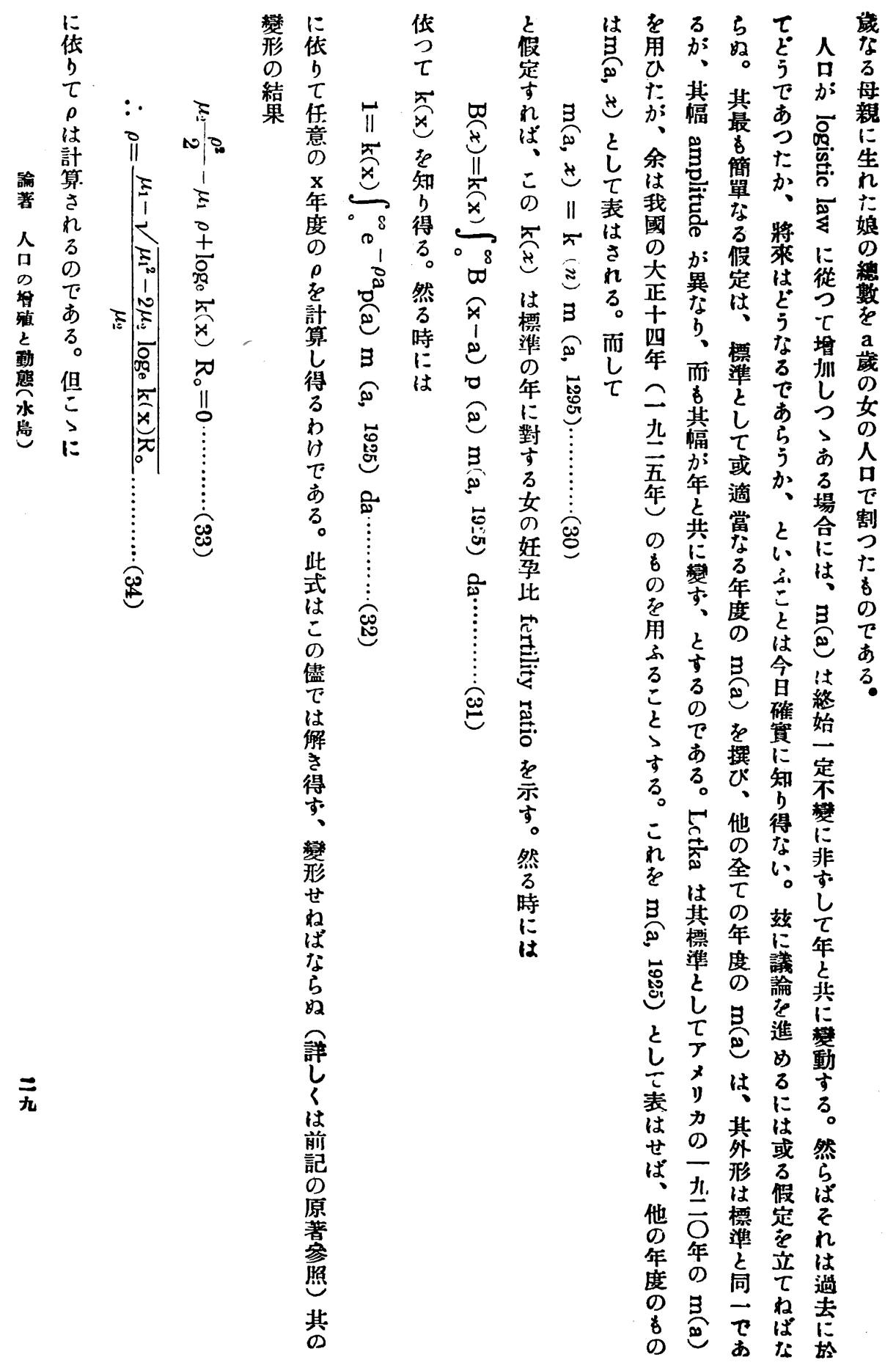




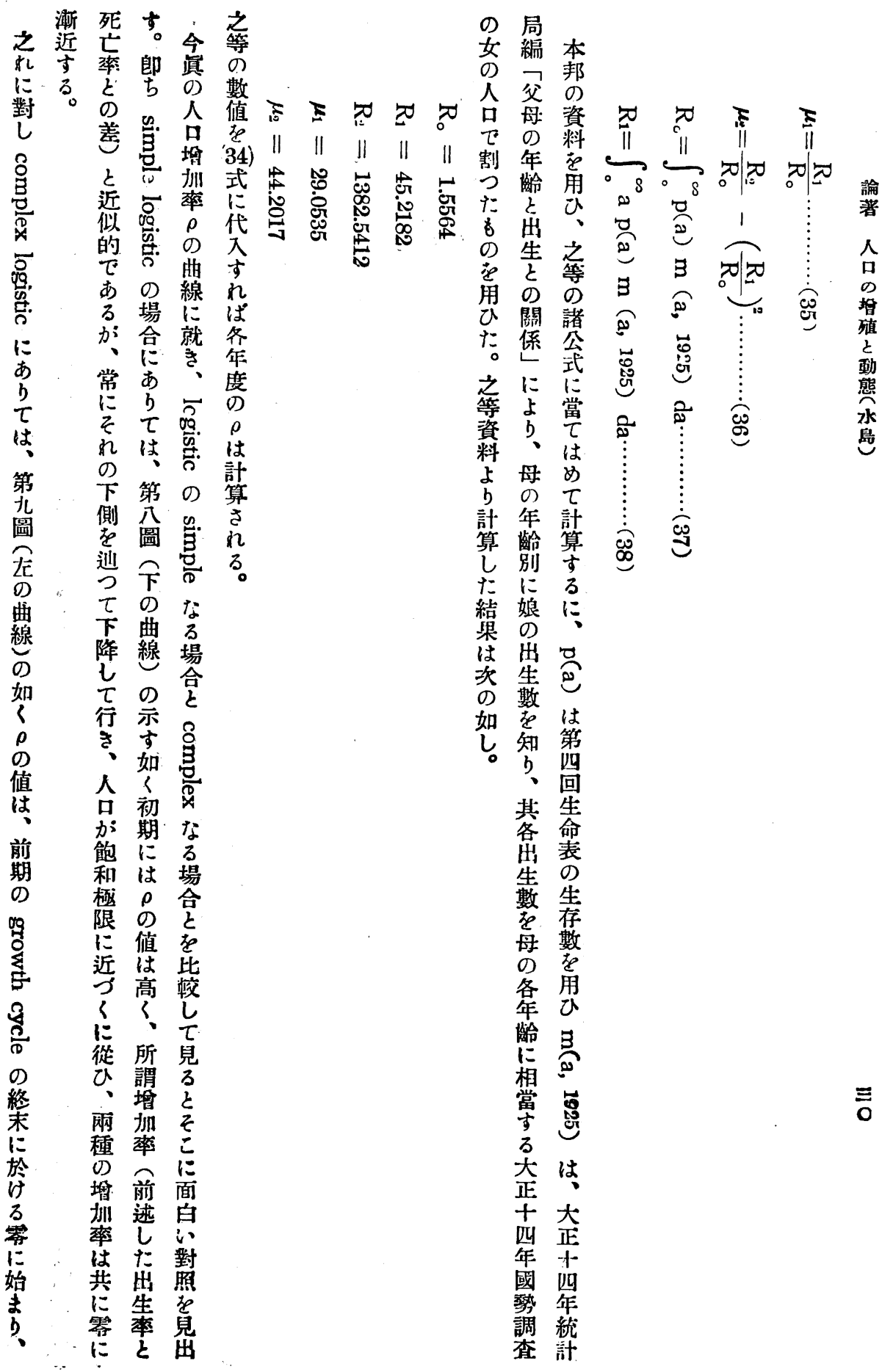


第十圆本均迷兒酸(一人の女の一生涯に付)

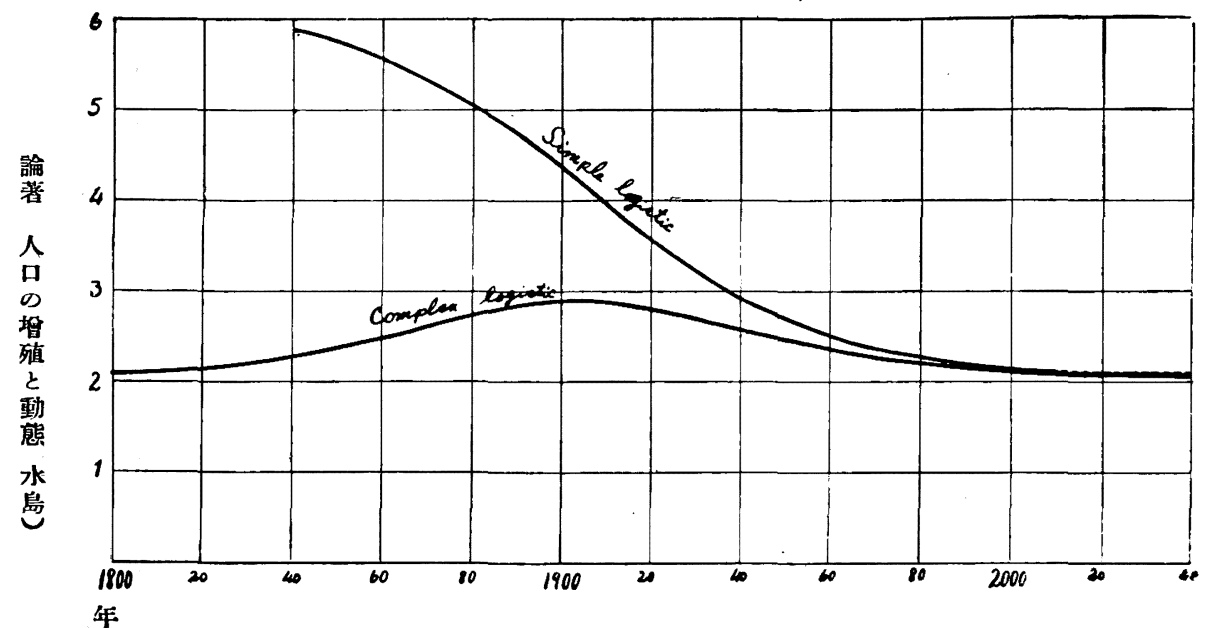

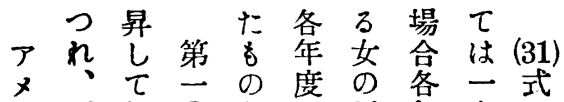

$$
\begin{aligned}
& \text { 》再極○枚作年九に } \\
& \text { カ片大圖圖於均度三よ } \\
& \text { に二にの示け﨎に五b } \\
& \text { 於 - 達下卞 } 3 \text { 兒於年 }
\end{aligned}
$$

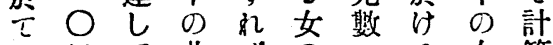

$$
\begin{aligned}
& \text { はにて曲ばのつる女算 } \\
& \text { 漸峯線第出男女均市弤得 }
\end{aligned}
$$

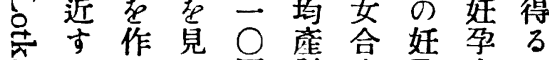

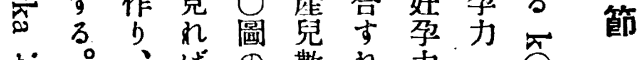

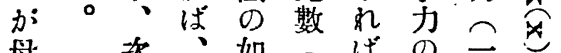

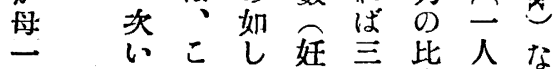

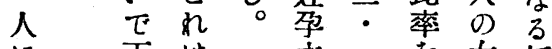

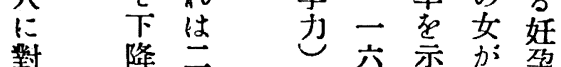

$$
\begin{aligned}
& \text { す ᄂ } \dot{0} \text { 六す生比 } \\
& \text { 年行 } \\
& \text { 平行量方白团力 }
\end{aligned}
$$

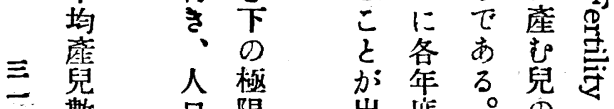

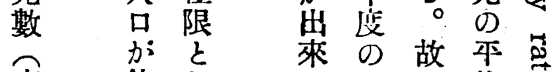

$$
\begin{aligned}
& \text { 妻 飽主 } \\
& \text { の 和元 斯 妾云整 } \\
& \text { 七限發々を光を次 } \\
& \text { - にし ᄂ 乘五標日 } \\
& \text { 布近、守年準本 } \\
& \% \text { 子潮計れに上に } \\
& \text { 不に次算ば於した }
\end{aligned}
$$




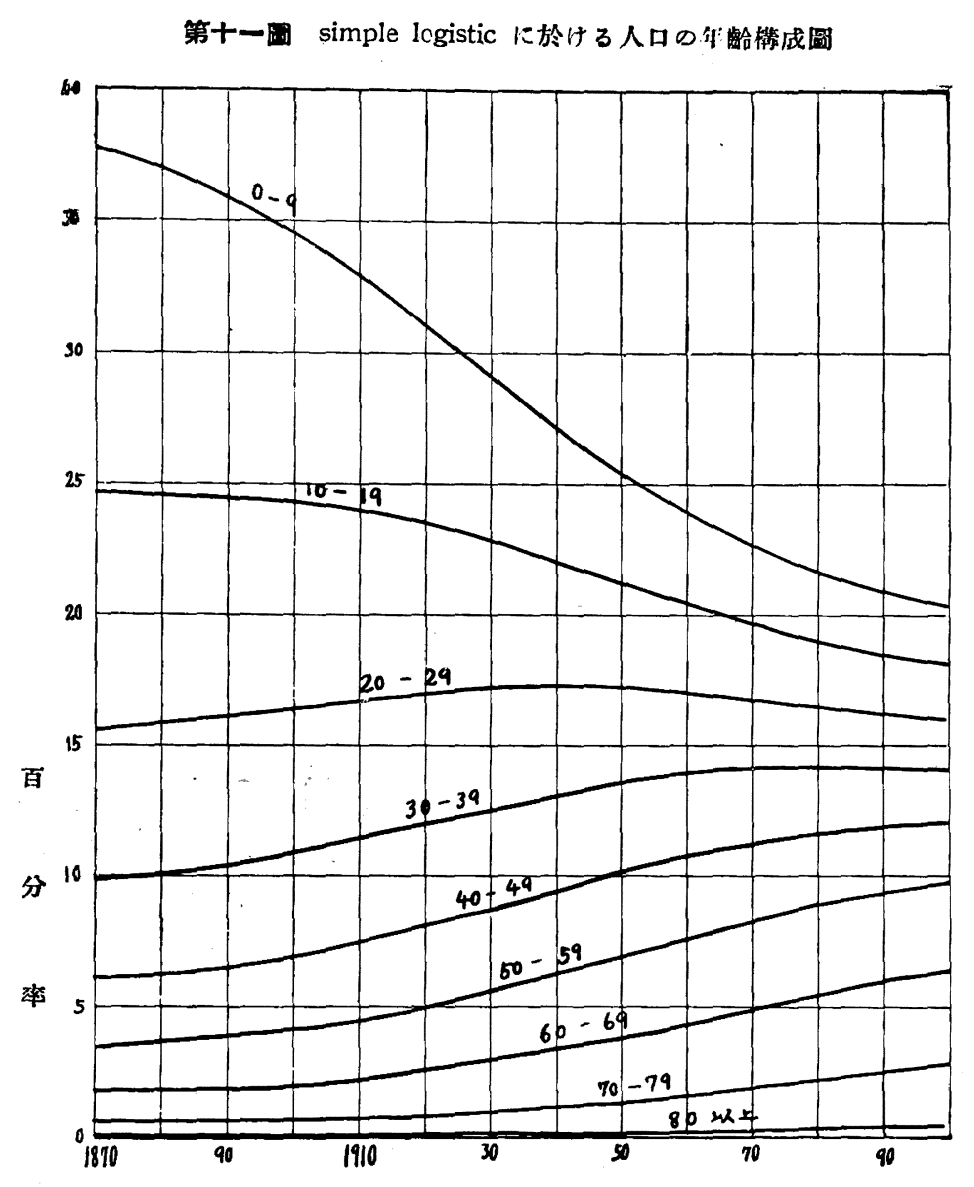

등

就な

$\widetilde{\tau} \frac{d}{b}$

女

क $\tau$

妊

古驽娄

吕訪

は計莧

初算 $\tau$

期 万

に桔方。

著穼例

しᄂ

亭第已 永

高 $\overrightarrow{0}$ 管

圖 ह

漸高記

焁上の

の 余

降曲尔

線計

算

遂あし

E

此 -

○生

渐曲涯

潫線 0 )

近和平

石均

。鼠

榓 鼠

か

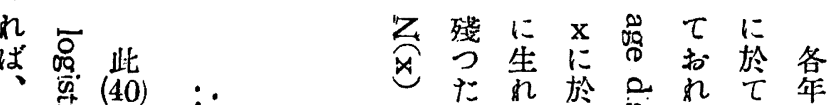

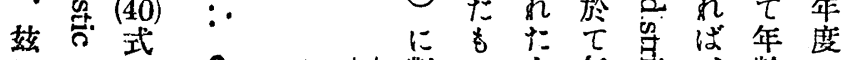

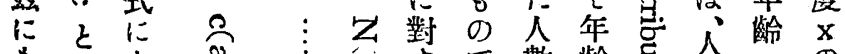

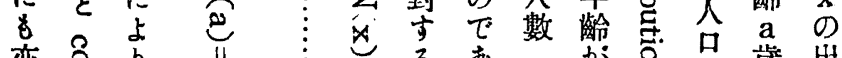

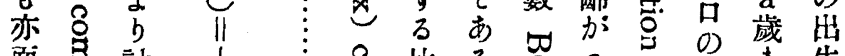

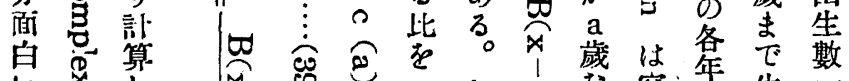

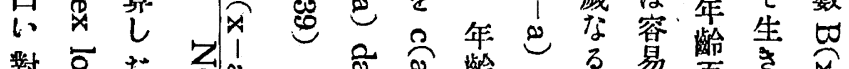

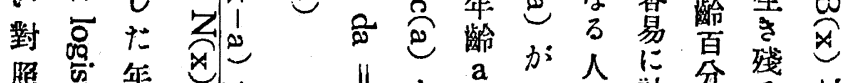

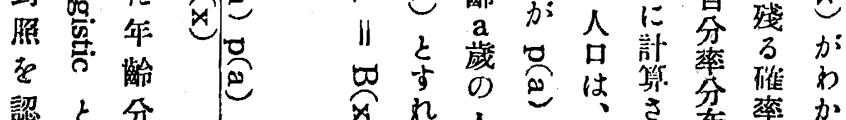

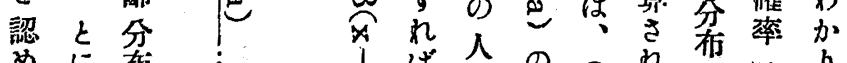

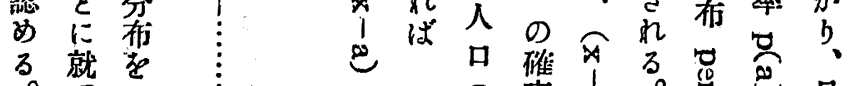

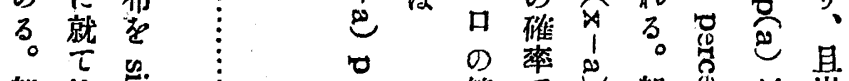

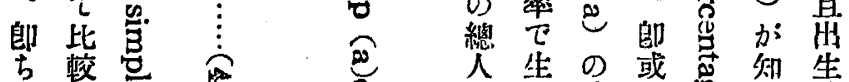

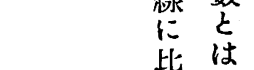

守 直

第

古

衬

ばに

飞比

の較

形学

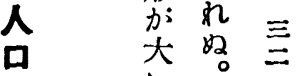

の

年㬴本

齡寒の

構方。

即窎

古

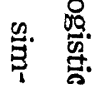




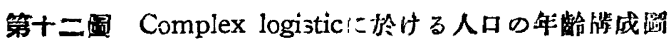

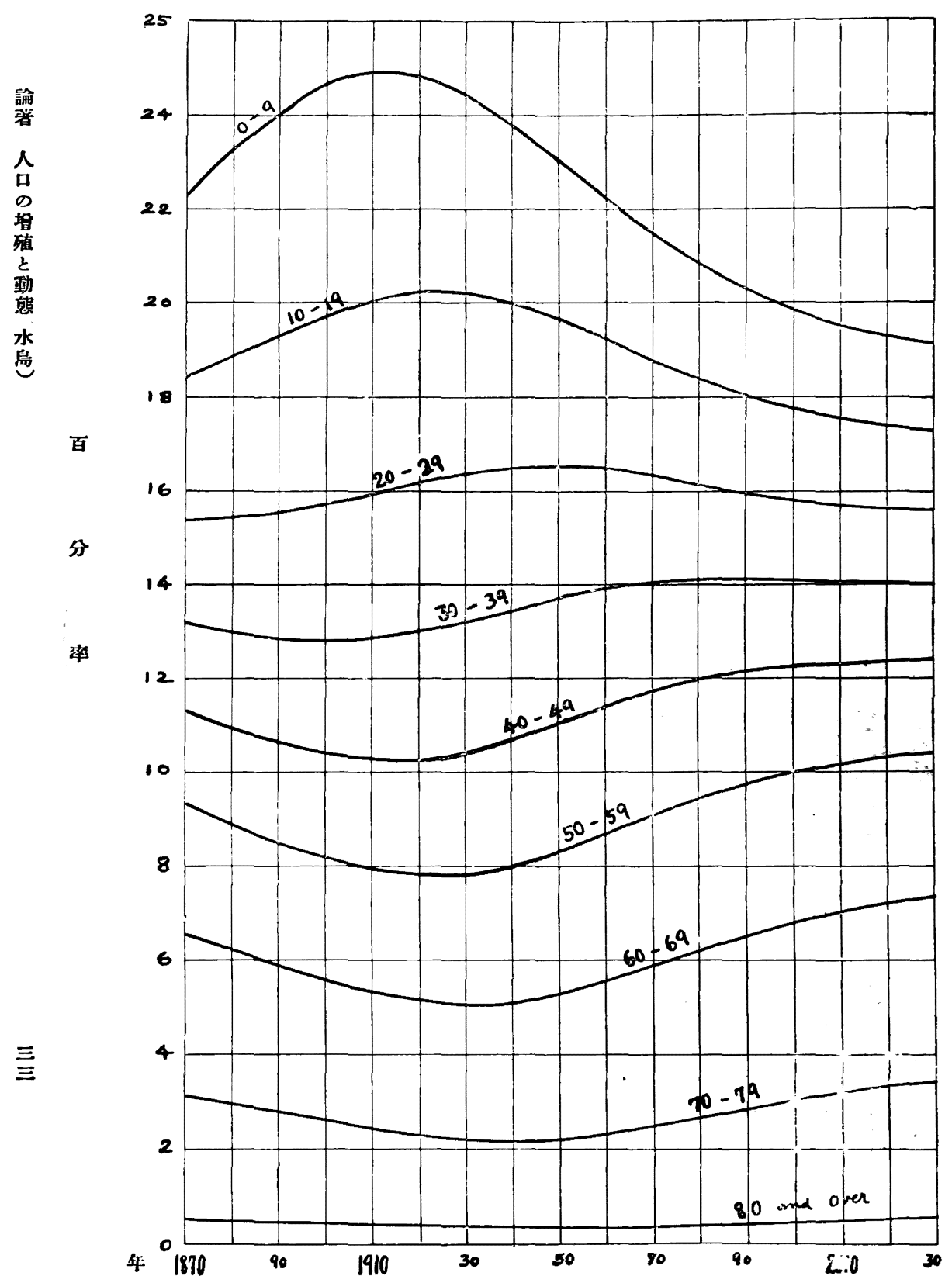




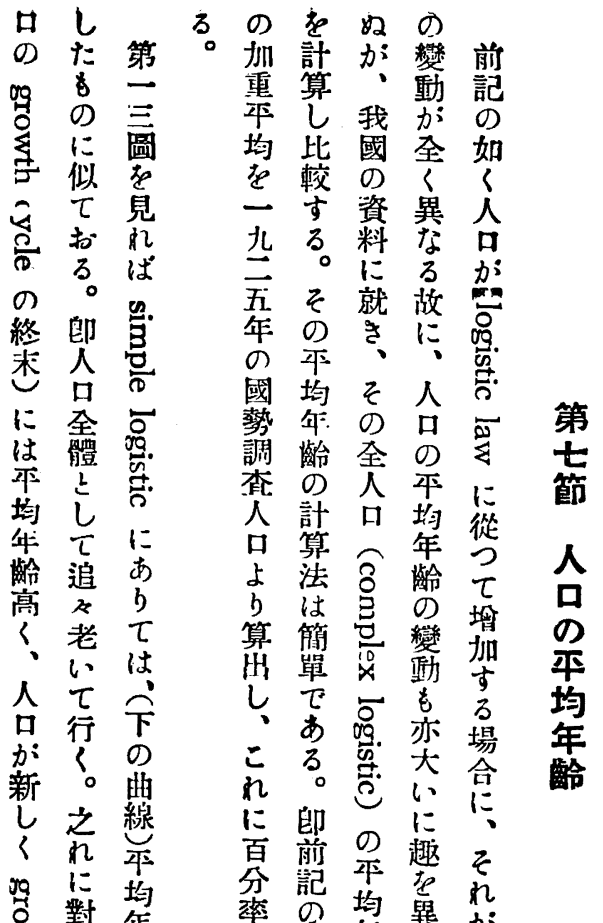

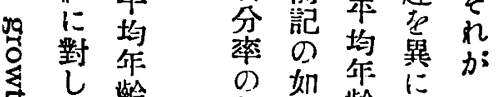

志龄 數了龄卞

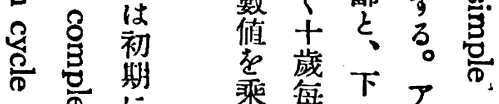

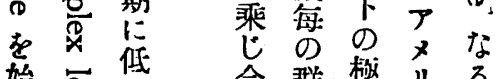

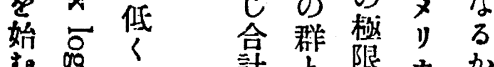

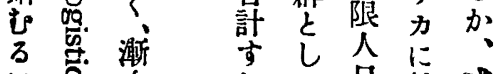

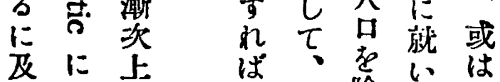

て

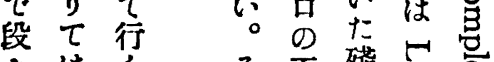

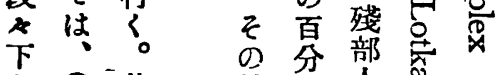

b卡結率人地な

一のの柴が口が

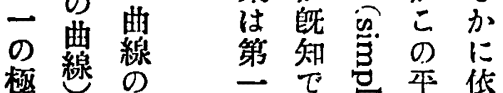

極愁京形艺㝵平依

に初は非國方年 、

達期 S

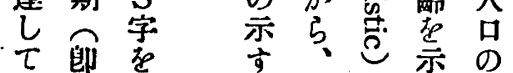

谷古引通备のし年

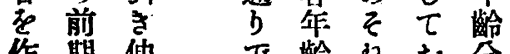

作期伸罂短记分

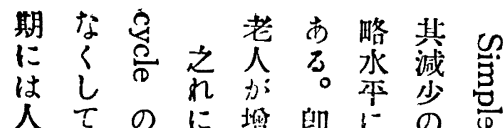

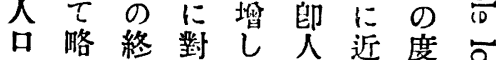

は水沫して兄は哭

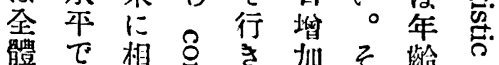

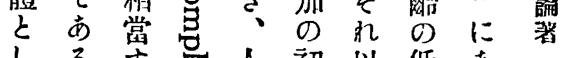

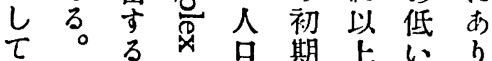

老飞故灾は期卡程元吕

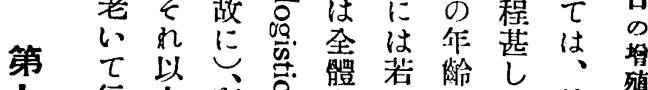

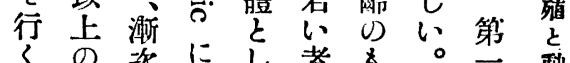

年管 あ光者

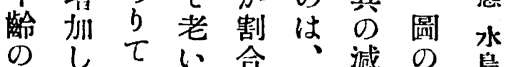

。注初少加岛

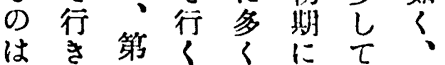

極三の高劣行若

初大示で年なくい

期に圖あ者々曲年

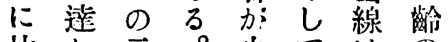

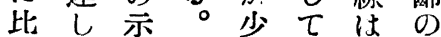

較てすな漱逆者

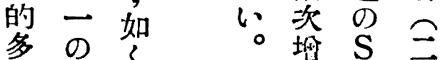

山若人扠字 $\vec{D}$

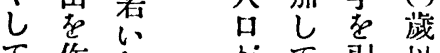

$\tau$ 作年 少元引以

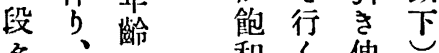

減次 二 和く。伸

岁分 限そし初

て藏にのた期

一下以近增形に

のつ赑势に多

谷 $\longleftarrow$ く 似

を行のに曲 $\tau$

作了者線お年

つ。者的るか

$\tau$ 二初、正。移

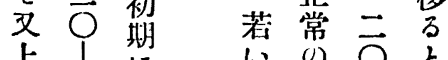

上卡少 者 $\mathrm{S}$ 个共

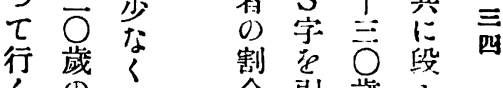

く 00 合引留

印 者盖減仲階少

こ此前蒈は級し

の際䐓、しは兄

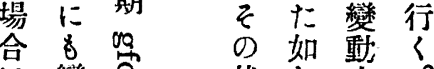

に 


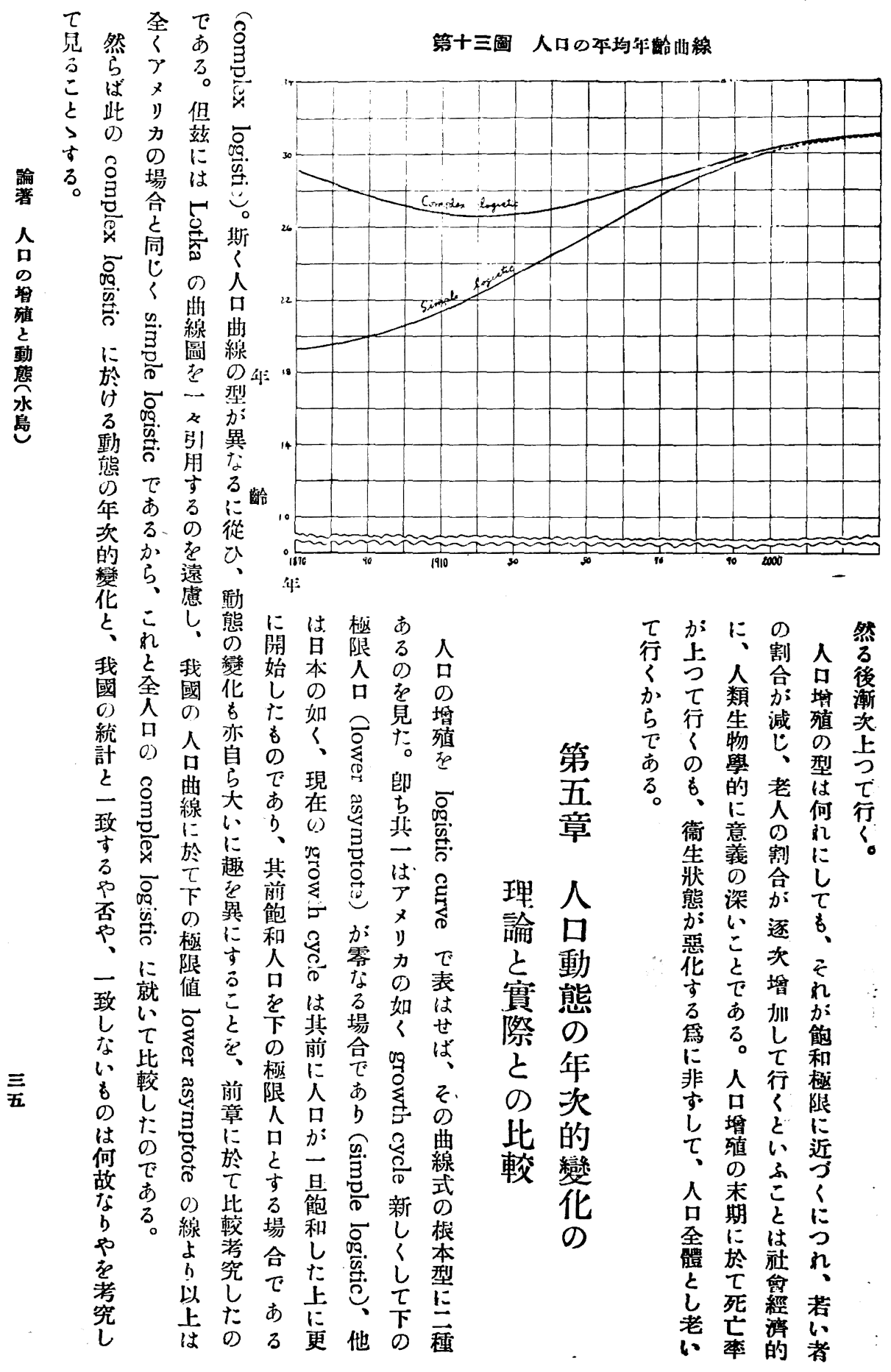




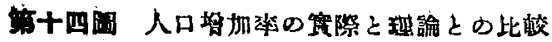

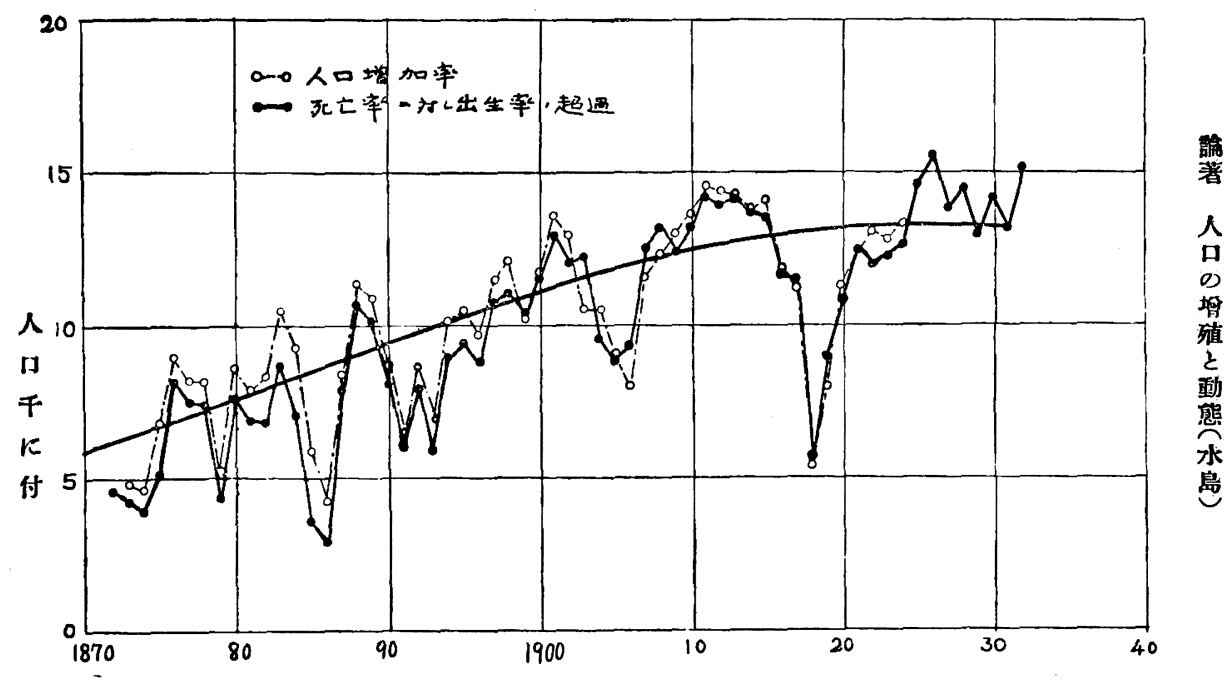

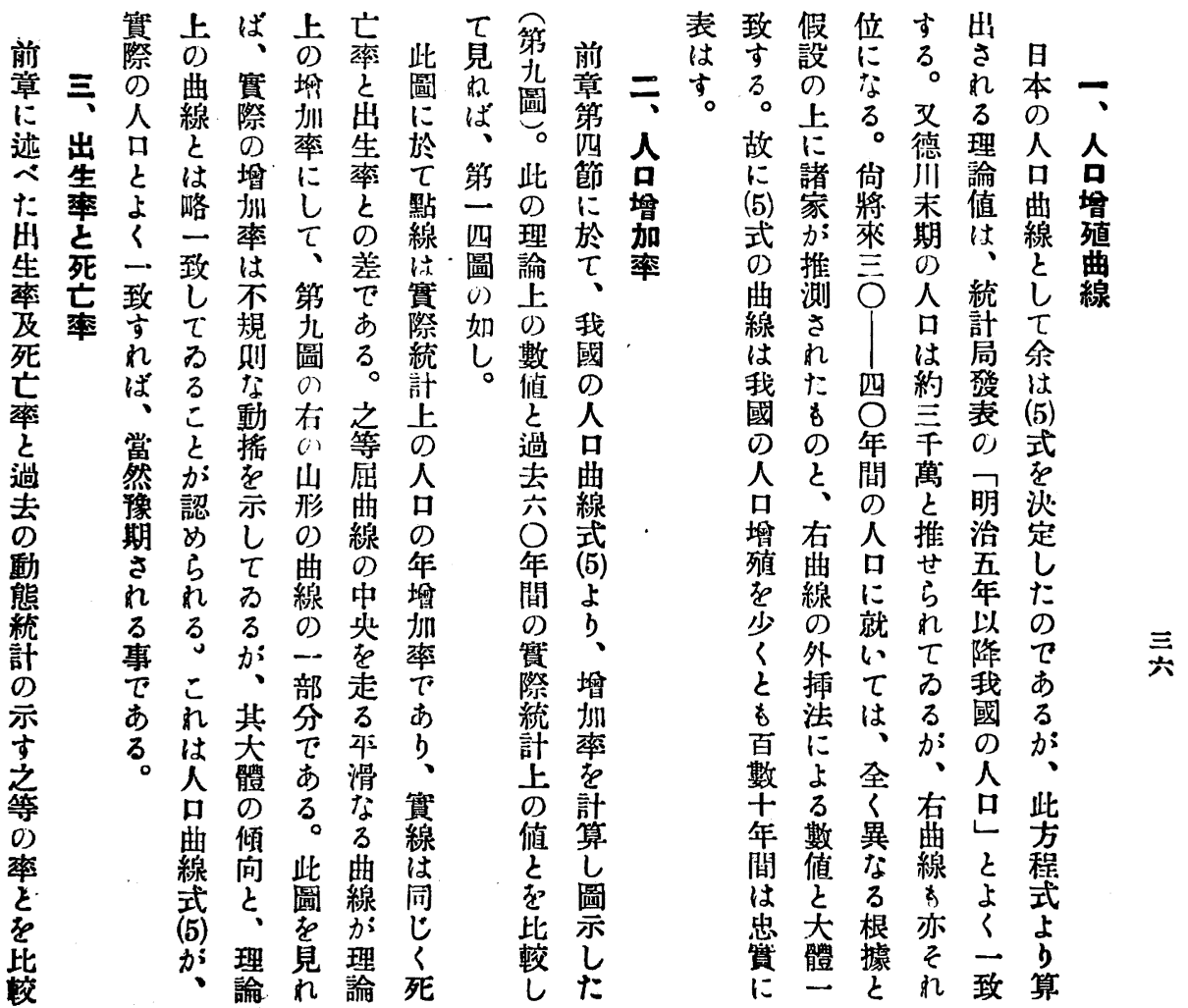


第十五圆 出生率及死し率の现論と筷際との比較

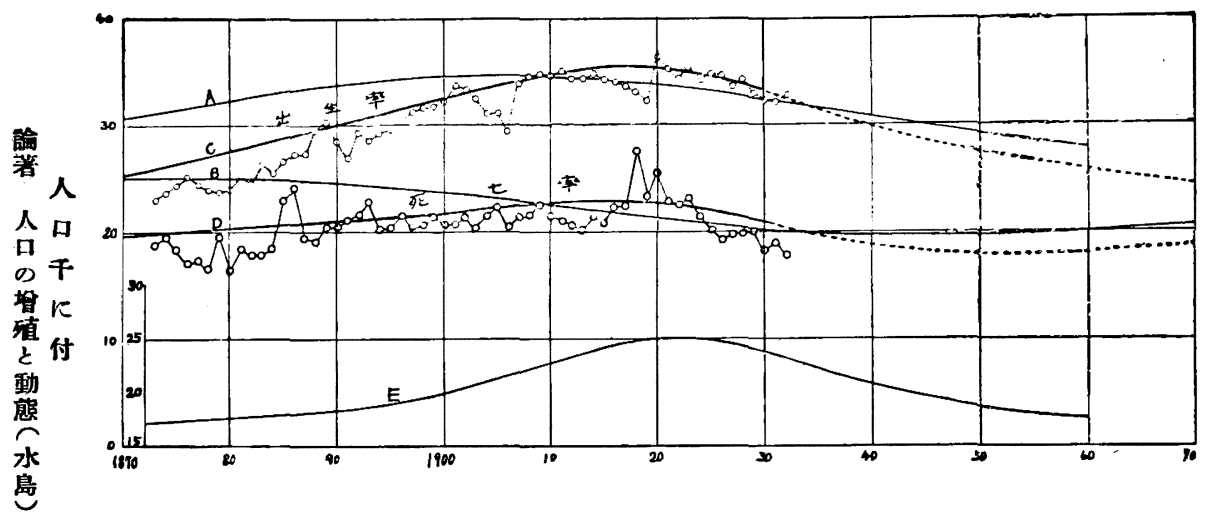

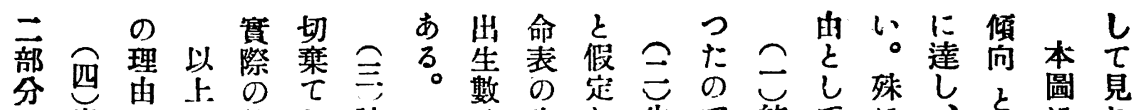

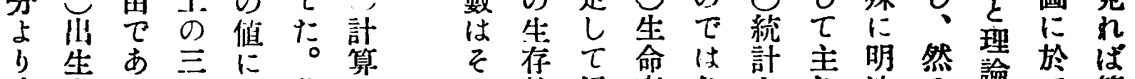

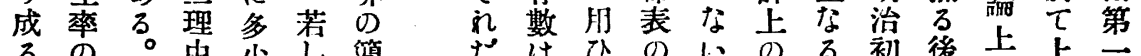

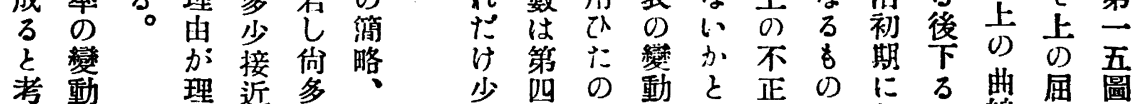

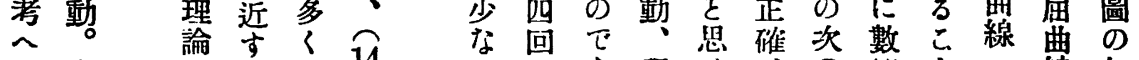

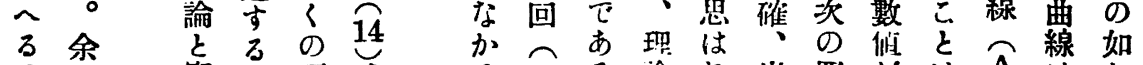

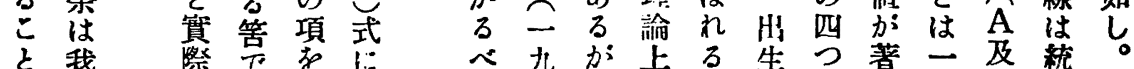

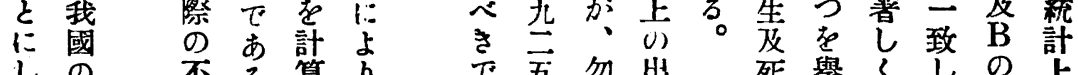

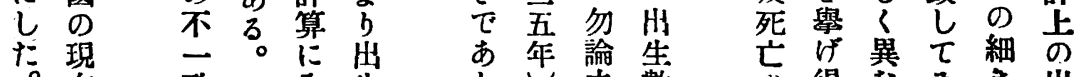

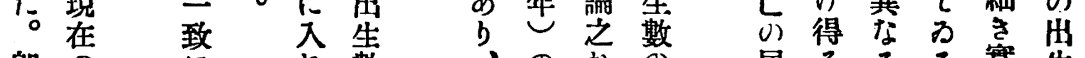
郎の

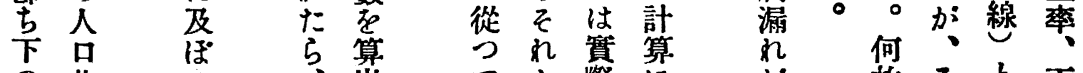

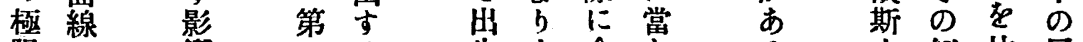

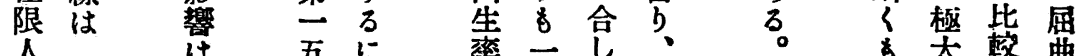

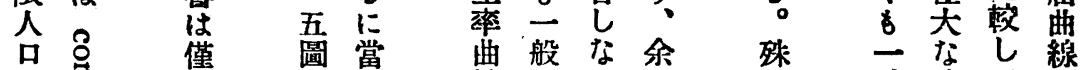

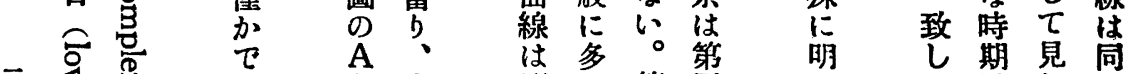

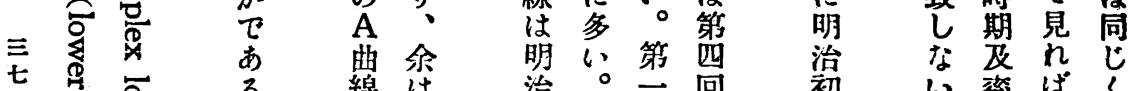

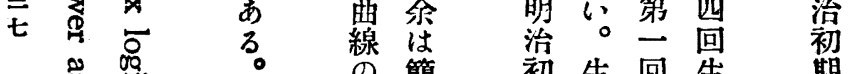

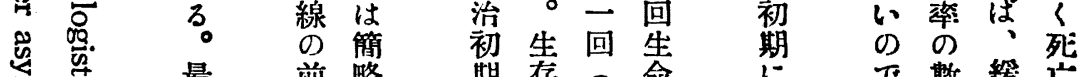

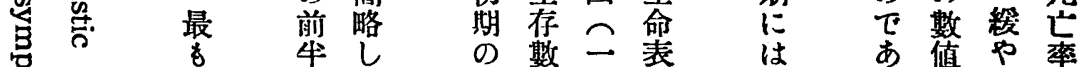
总に 辛 交 今第若け $\supseteqq$ 終方方良にあ

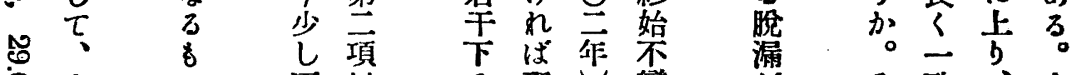

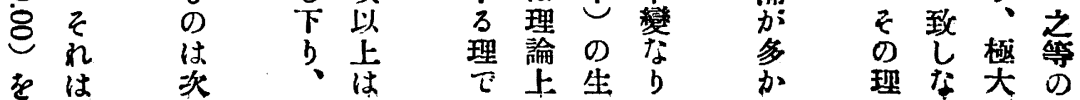




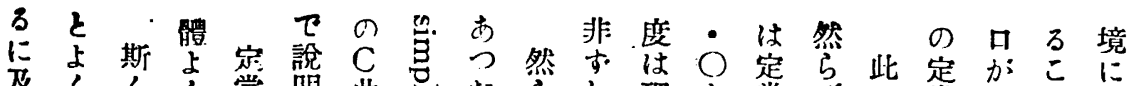
及くくく家

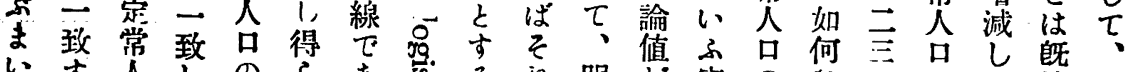

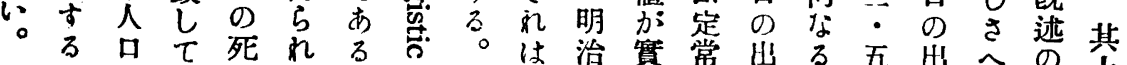

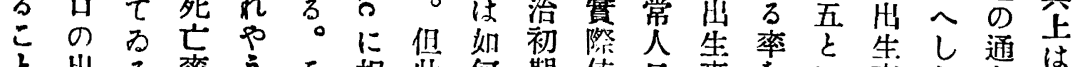

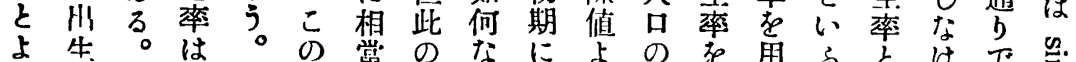

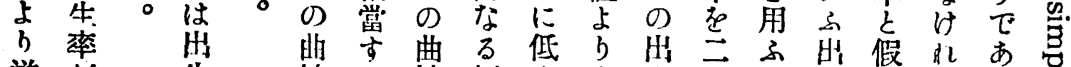

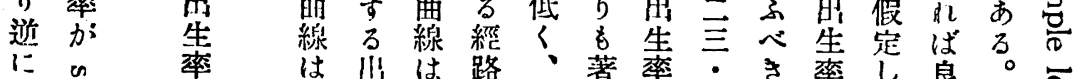

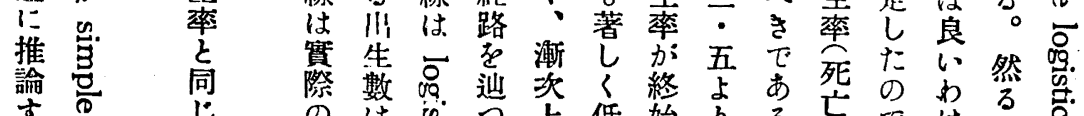

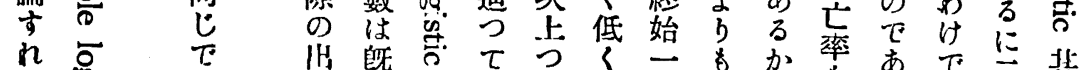

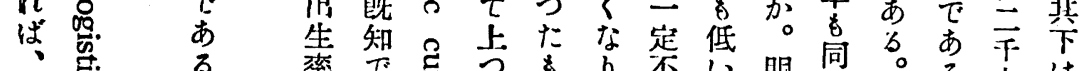
該合

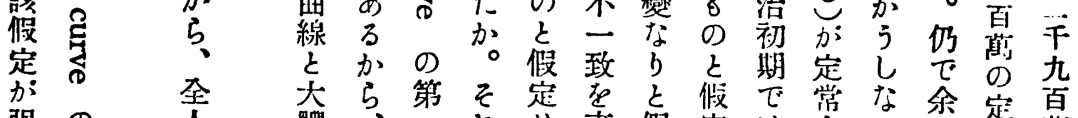

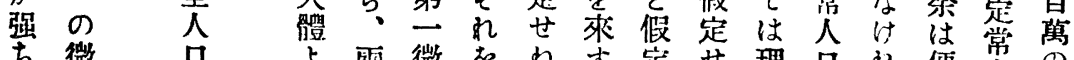

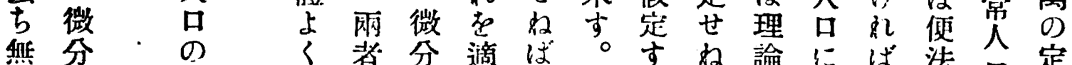

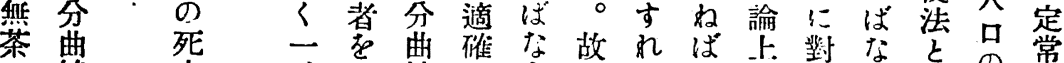

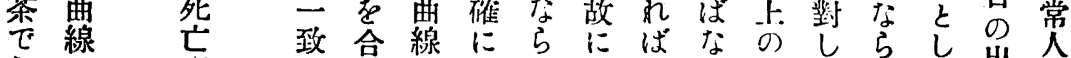

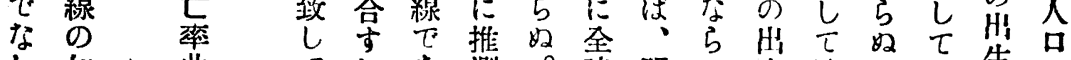

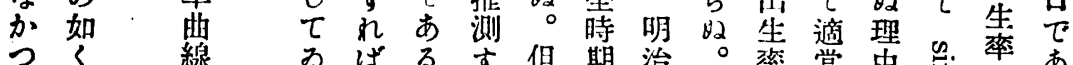

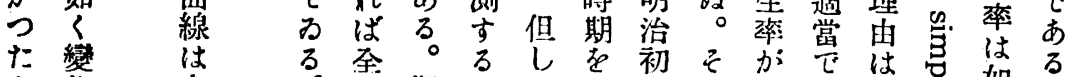

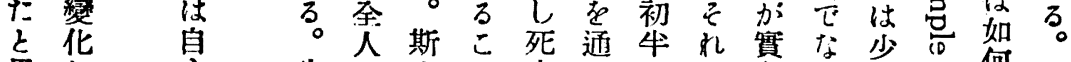

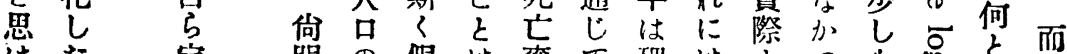

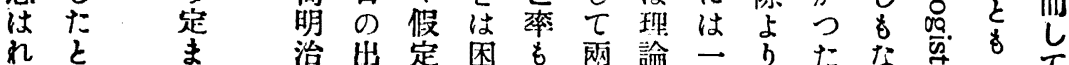

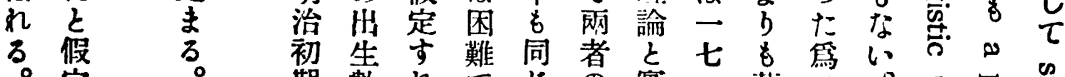

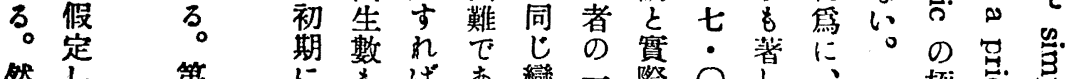

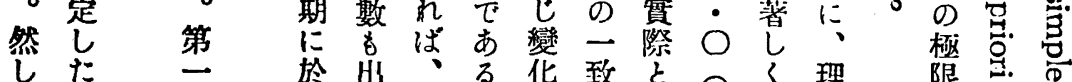

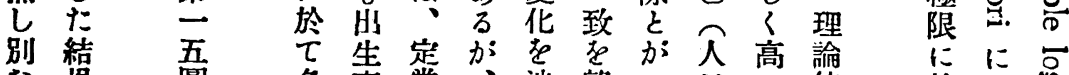

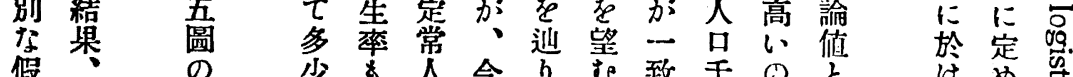

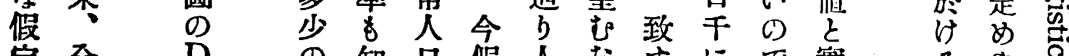

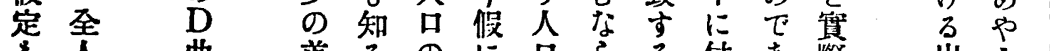

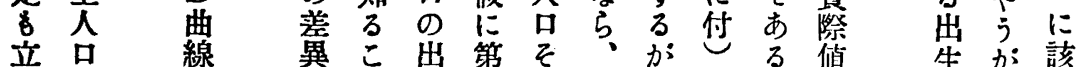

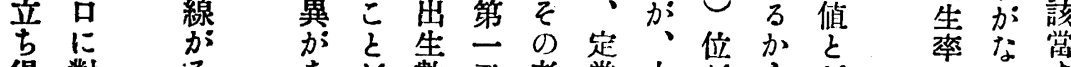

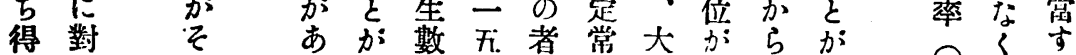

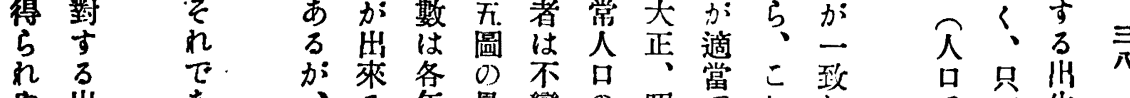

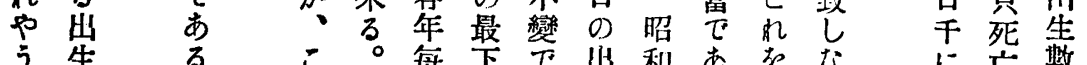

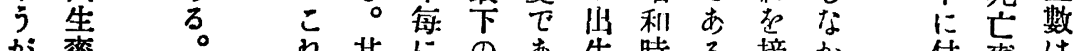

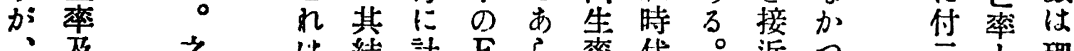

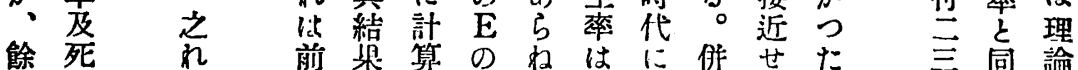

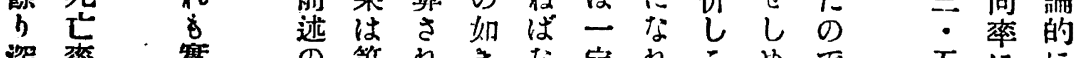
深率 䨳

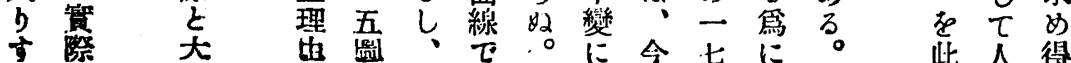




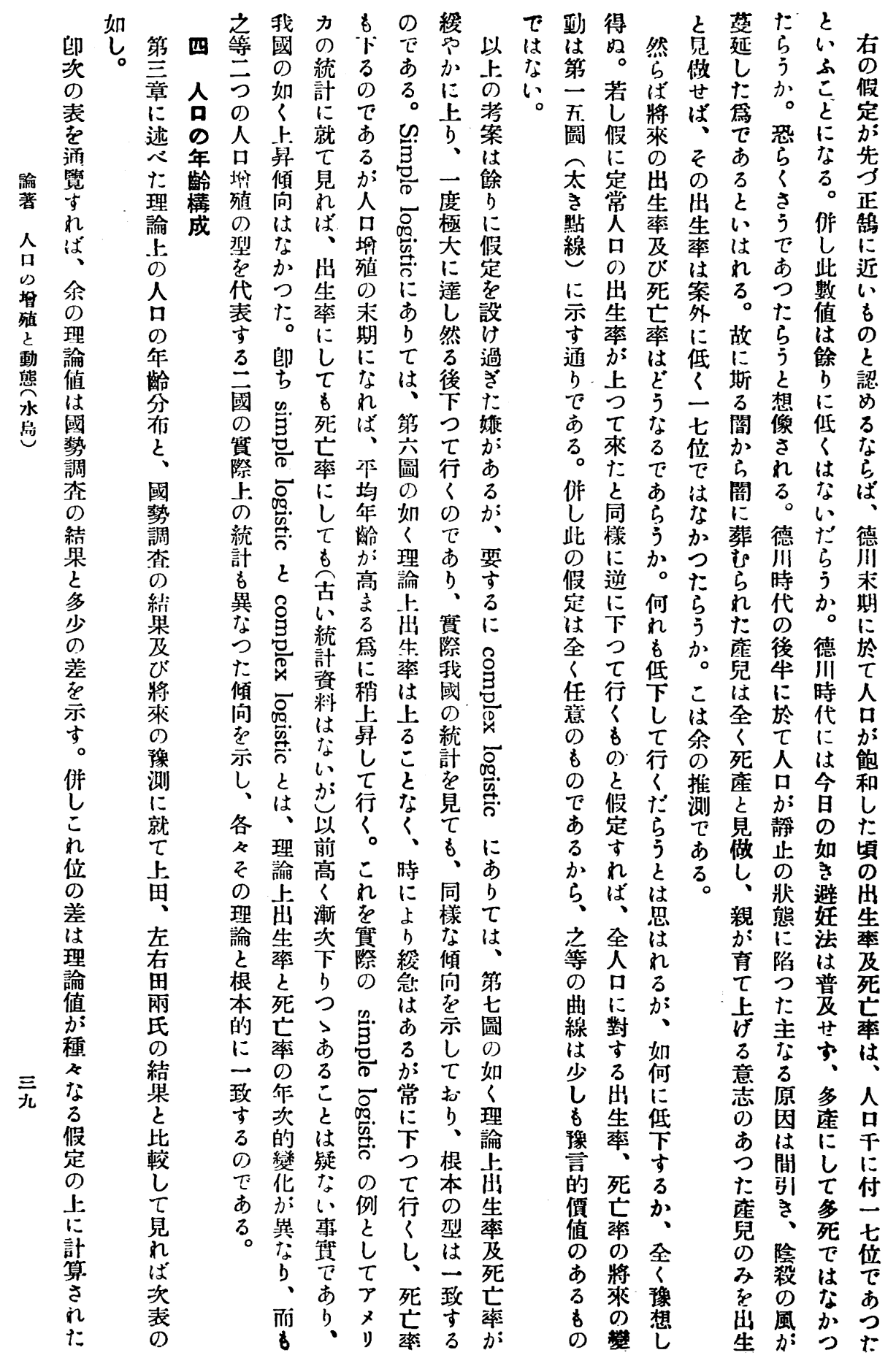




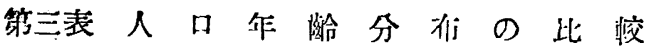

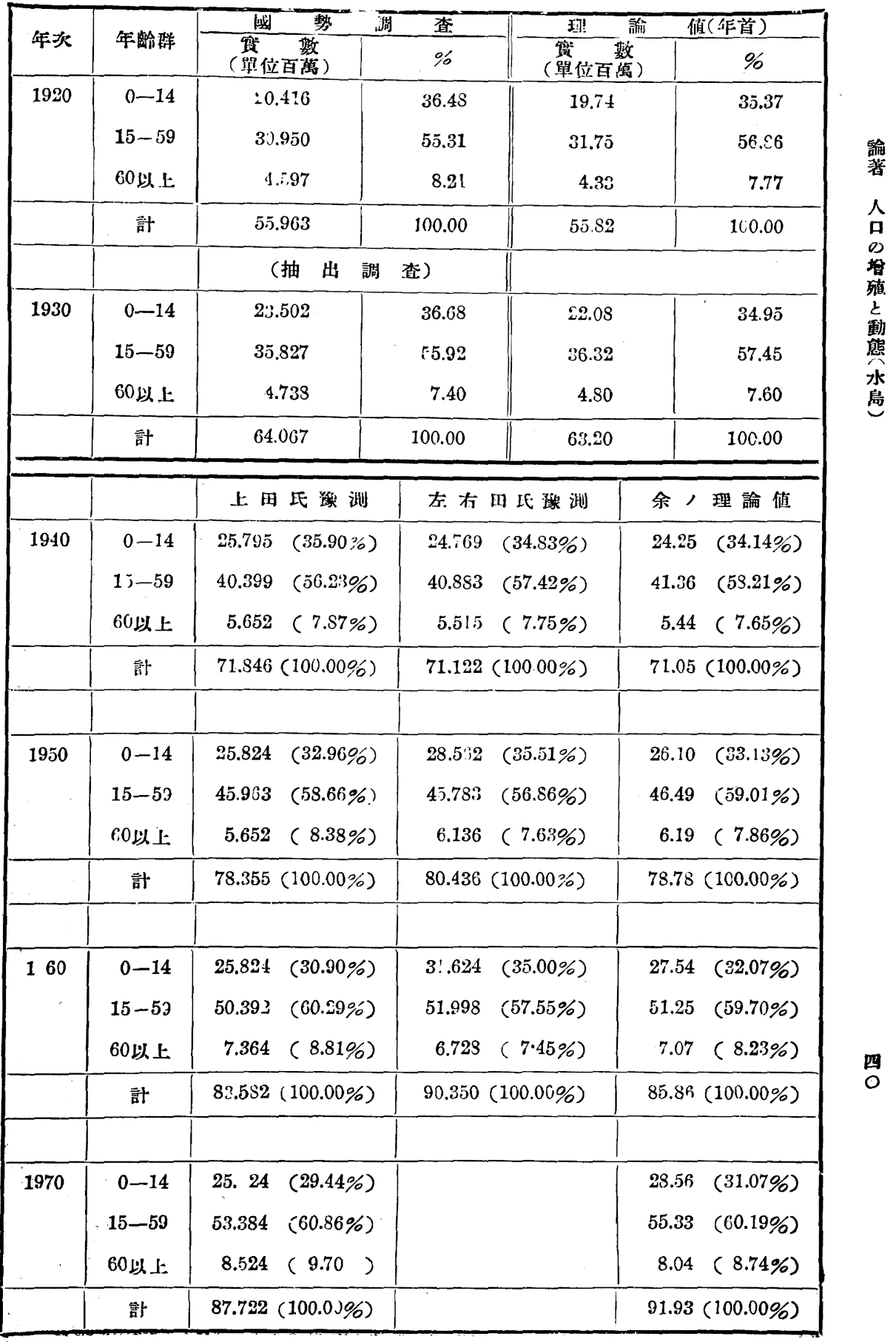




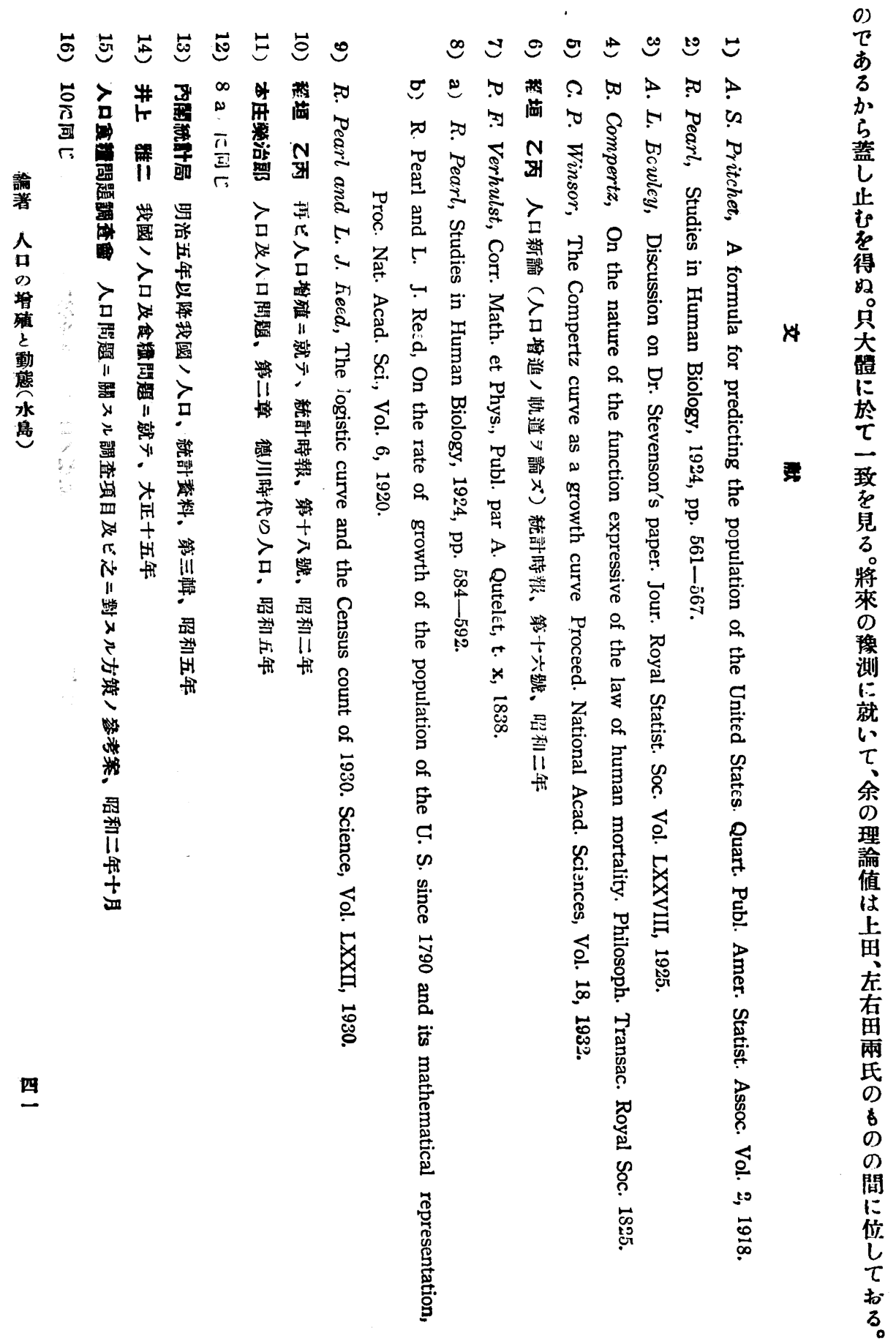




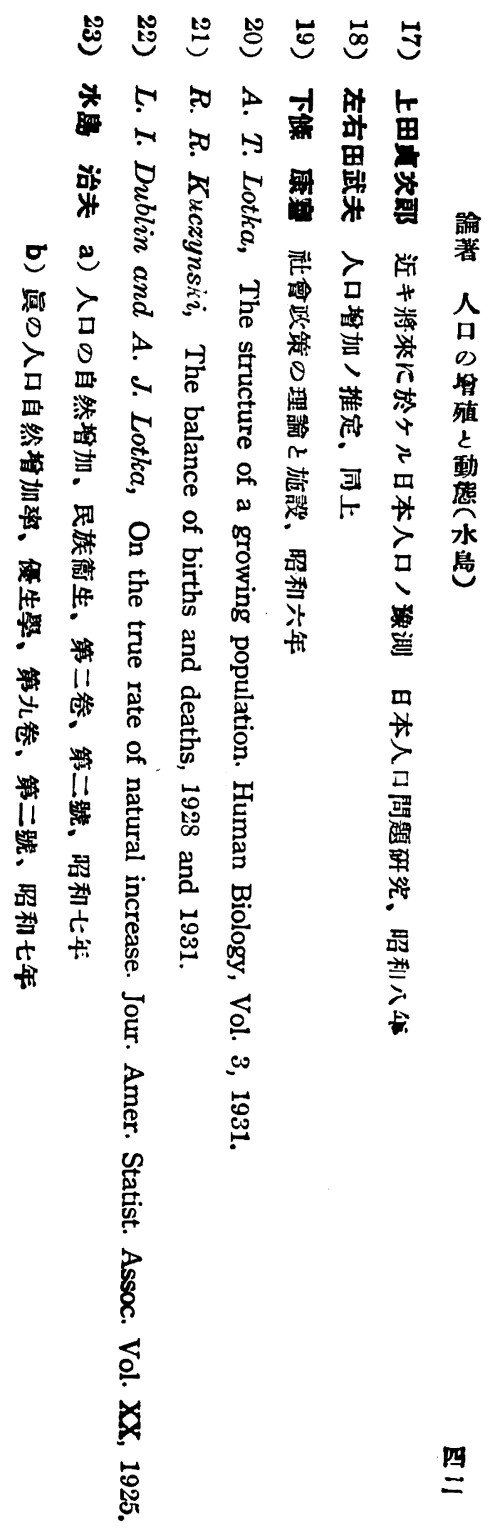




\title{
Growth and Structrue of Population
}

\author{
By
}

\author{
Haruo Mizushima, M. D., Dr. P. H.
}

The population growth of the United States is well expressed by Reed and Pearl with a logistic equation,

$$
\mathrm{y}=\frac{197.274}{1+67.3 \mathrm{e}^{-0.0313 \mathrm{x}}}
$$

where $\mathrm{y}$ is population in millions, and the origin of $\mathrm{x}$ is 1870 . One of the characteristics of this logistic curve is that its lower asymptote is zero. I may provisionally call this type of curve as simple 1 gistic.

According to Lotka, such a populat on, which has for an extended period of time been following the logistic law, has a definite pattern. Its demographic characteristics are not fortuitous or capricious, but conform to a type or model determined by the logistic law of growth itself.

To the population growth of Japan since the latter half of the Tokugawa Shogunate era (about 1830) the following equation can with good agreement be fitted,

$$
y=29.00+\frac{81.00}{1+e^{2.653-0.039 x}},
$$

where the origin of $x$ is 1870 . The lower asymptote of this curve is not zero, but a definite value, 29 millions. This type of curve may provisionally be called as complex logistic.

Due to the difference of the lower asymptotes the secular changes of the demographic characteris ics of the complex log:stic are quite different from those of the simple logistic. By the same procedure as demonstrated by Lotka, I computed, availing the data of Japan, the demographic characteristics such as the number of births and deaths, the birthrate and 
the deathrate, the apparent and the true rate of population increaae, the fertility rate of female, the age composition and the average age of population for both simple and complex logistic, and the peculiar changes of these demograghic structures are compared each other.

(Author's abstract) 